\title{
Effect of pyrolysis temperature on Si release of alkali-enhanced Si-rich biochar and plant response
}

\author{
Meng Wang ${ }^{1,2,3} \cdot$ Negar D. Tafti ${ }^{2} \cdot \operatorname{Jim} \mathrm{J}$. Wang $^{2}$ (C) Xudong Wang ${ }^{3}$
}

Received: 23 March 2021 / Accepted: 1 July 2021 / Published online: 27 July 2021

(c) The Author(s) 2021

\begin{abstract}
Recent studies have shown that silicon ( $\mathrm{Si}$ ) dissolution from biochar may be influenced by the pyrolysis temperature. In addition, the enhancement of biochar by treatment with alkali has been proposed to produce a Si source that can be used for environmentally friendly plant disease control. In this study, biochars from rice straw and rice husk pretreated with $\mathrm{KOH}$, $\mathrm{CaO}$ and $\mathrm{K}_{2} \mathrm{CO}_{3}$ and then pyrolyzed at 350,450 and $550{ }^{\circ} \mathrm{C}$ were prepared to evaluate the effects of pyrolysis temperature on $\mathrm{Si}$ release and plant uptake from alkali-enhanced Si-rich biochar. Extractable $\mathrm{Si}$ and dissolution $\mathrm{Si}$ from the prepared biochars were assessed by different short-term chemical methods and long-term (30-day) release in dilute acid and neutral salt solutions, respectively, along with a rice potting experiment in greenhouse. For both rice straw- and husk-derived alkali-enhanced biochars (RS-10KB and HS-10K2B, respectively), increasing the pyrolysis temperature from 350 to $550{ }^{\circ} \mathrm{C}$ generally had the highest extractable $\mathrm{Si}$ and increased $\mathrm{Si}$ content extracted by 5 -day sodium carbonate and ammonium nitrate (5dSCAN) designated for fertilizer Si by $61-142 \%$, whereas non-enhanced biochars had more extractable $\mathrm{Si}$ at $350{ }^{\circ} \mathrm{C}$. The alkali-enhanced biochars produced at $550{ }^{\circ} \mathrm{C}$ pyrolysis temperature also released $82-172 \%$ and $27-79 \%$ more Si than that of $350{ }^{\circ} \mathrm{C}$ produced biochar in unbuffered weak acid and neutral salt solutions, respectively, over 30 days. In addition, alkali-enhanced biochars, especially that derived from rice husk at $550{ }^{\circ} \mathrm{C}$ facilitated $6-21 \%$ greater Si uptake by rice and 44-101\% higher rice grain yields than lower temperature biochars, non-enhanced biochars, or conventional Si fertilizers (wollastonite and silicate calcium slag). Overall, this study demonstrated that $550{ }^{\circ} \mathrm{C}$ is more efficient than lower pyrolysis temperature for preparing alkali-enhanced biochar to improve $\mathrm{Si}$ release for plant growth.
\end{abstract}

Keywords Silicon $\cdot$ Biochar $\cdot$ Extractable $\mathrm{Si} \cdot \mathrm{Si}$ release $\cdot$ Plant uptake

\section{Introduction}

The beneficial effect of Si on plant growth has been well documented. It includes improving plant resistance to pest and disease, enhancing mechanical strength, and decreasing nutrient imbalance, as well as alleviating metal toxicity and other stresses due to soil salinity, extreme temperature

Jim J. Wang

jjwang@agcenter.1su.edu

1 College of Chemical and Environment Science, Shaanxi University of Technology, Hanzhong, Shaanxi 723001, China

2 School of Plant, Environmental and Soil Science, Louisiana State University, 104 Sturgis Hall, Baton Rouge, LA 70803, USA

3 College of Natural Resources and Environment, Northwest A\&F University, Yangling, Shaanxi 712100, China and drought conditions (Meyer and Keeping 2001; Neumann and Zur 2001; Epstein 2009; Guntzer et al. 2012; Adrees et al. 2015; Islam et al. 2020). Thus, the application of Si fertilizers to plants, especially $\mathrm{Si}$-accumulators such as rice, maize, sugarcane, wheat, and ryegrass is necessary to ensure plant healthy growth. Recently, several studies have shown that biochars produced by pyrolyzing Si-rich waste biomass could be also used as bioavailable $\mathrm{Si}$ source to $\mathrm{Si}$ accumulator plants (Houben et al. 2014; Liu et al. 2014; Li et al. 2014, 2018; Abbas et al. 2017; Linam et al. 2021). Application of biochars significantly increased Si content in stem and blades of wheat, rice, and perennial ryegrass (Liu et al. 2014; Abbas et al. 2017; Wang et al. 2018a, 2019a). Therefore, biochar could serve as a low-cost, renewable, and environmentally friendly Si source.

The characteristics of biochar are influenced by various factors, including feedstock biomass types and pyrolysis conditions. Pyrolysis temperature has been considered as 
one of the most important factors affecting physical, chemical and structural characteristics of biochar (Singh et al. 2012; Keiluweit et al. 2010; Nguyen et al. 2010; Kuzyakov et al. 2009). Compared with biochars prepared at low temperatures, high-pyrolysis temperature biochars tend to have higher carbon content, $\mathrm{pH}$, ash content, specific surface area, aromatization and thermal stability, but exhibit lower nitrogen content, yield, and aliphatic carbon fractions (Huang et al. 2020; Suliman et al. 2016; Ahmad et al. 2012; Kim et al. 2012; Novak et al. 2009).

Pyrolysis temperature also affects the interaction of carbon with silicon in biochar. For biomass feedstocks that are rich in amorphous silicon, it was reported that pyrolysis in the temperature range of $250 \sim 350{ }^{\circ} \mathrm{C}$ could cause a crack of carbon layer in the $\mathrm{C}-\mathrm{Si}-\mathrm{C}$ structural configuration of biomass which exposes internal $\mathrm{Si}$ and leads to an increasing solubility of $\mathrm{Si}$ in biochar (Xiao et al. 2014). However, as pyrolysis temperature is further raised to $500 \sim 700{ }^{\circ} \mathrm{C}$, the solubility of $\mathrm{Si}$ is decreased due to aromatization of carbon and formation of more crystallized silica (Xiao et al. 2014). On the other hand, a new study reported generally continuous increase in accumulative Si dissolution from several biochars derived from both Si-rich and deficient biomass feedstocks as pyrolysis temperature increased from 300 to $700{ }^{\circ} \mathrm{C}$ (Wang et al. 2018b). While Si release rates for Si-rich biochars were found to be similar at different pyrolysis temperatures with different final amounts of total Si released, the Si-deficient biochars showed a high and low stages of Si release rates but with no difference in the final amount of total Si dissolved (Wang et al. 2018b). In addition, others also reported the increasing extractable Si content of rice husk and sugarcane bagasse biochars based on chemical extractions as pyrolysis temperature increased from 300 to $700{ }^{\circ} \mathrm{C}$ (Nwajiaku et al. 2018). These results suggest the solubility of $\mathrm{Si}$ or $\mathrm{Si}$ availability of biochar likely depends on the interaction between the specific feedstock and pyrolysis temperature. These biochar Si solubility characteristics have not been evaluated in regard to plant response. On the other hand, Wang et al. (2018a,2019a) recently proposed the use of alkali-enhanced biochar as Si fertilizer. However, the effects of pyrolysis temperature on the properties of alkalienhanced biochars have not yet been explored.

In this study, rice straw and husk were selected to prepare $\mathrm{KOH}, \mathrm{K}_{2} \mathrm{CO}_{3}$ and $\mathrm{CaO}$-enhanced Si-biochars at different pyrolysis temperatures. The effects of temperature on physical and chemical properties as well as total and extractable $\mathrm{Si}$ were investigated. In addition, since the dissolution tendency of $\mathrm{Si}$ in Si fertilizer was highly correlated with $\mathrm{Si}$ content released into soil (Korndörfer et al. 2001; Sebastian et al. 2013; Xiao et al. 2014), soil available Si for crop absorption could be simulated by acid or alkali extraction due to depolymerization of non-monomeric Si (Iler 1979; NIAES 1987; Bao 2000). Moreover, soil pH changes could affect biochar phytolith Si dissolution (Fraysse et al. 2006; Wang et al. 2018a). Therefore, weak acid and neutral salt solution were chosen to evaluate Si release of alkali-enhanced biochars prepared at different pyrolysis temperatures, and the associated plant response was measured to provide a basis for the rational application of alkali-enhanced biochar as an alternative Si source.

\section{Materials and methods}

\subsection{Alkali-enhanced biochar preparation}

Rice straw (RS) and husk (RH) collected from Louisiana State University AgCenter Rice Research Station (Crowley, LA, USA) were utilized for biochar preparation. Collected feedstock samples were rinsed using deionized (D.I.) water and then dried at $60{ }^{\circ} \mathrm{C}$ for $24 \mathrm{~h}$. The dried rice straw and husk biomass samples were ground to pass a 1-mm sieve using a cutting mill. For making biochar, rice straw and husk were mixed, respectively, with $\mathrm{KOH}, \mathrm{K}_{2} \mathrm{CO}_{3}$ or $\mathrm{CaO}$, in powder form and at alkali:biomass ratios (on weight basis) of 0:100, 5:100, and 10:100 in a porcelain crucible followed by mixing with $100 \mathrm{~mL}$ of D.I. water (for $50 \mathrm{~g}$ biomass) for $90 \mathrm{~min}$. The biomass-containing crucibles were then placed in muffle furnace under $\mathrm{N}_{2}$ flow at $400 \mathrm{~mL} \mathrm{~min}^{-1}$ to purge air from the system for $30 \mathrm{~min}$. Pyrolysis was carried out by setting muffle furnace temperature at $180^{\circ} \mathrm{C}$ for dehydration for $30 \mathrm{~min}$ and then maintaining at 350,450 and $550{ }^{\circ} \mathrm{C}$, respectively, for $60 \mathrm{~min}$ under $\mathrm{N}_{2}$ purge at $200 \mathrm{~mL} \mathrm{~min}{ }^{-1}$ (Wang et al. 2018a). The resulting biochar samples were cooled and ground to pass a 1-mm sieve before characterization. For convenience of discussion, these produced biochars are referred as $0 \mathrm{~B}$ (no alkali pretreatment), $5 \mathrm{~KB}$ and $10 \mathrm{~KB}$ (pretreatment with $\mathrm{KOH}$ at 5:100 and 10:100 ratio), 5K2B and $10 \mathrm{~K} 2 \mathrm{~B}$ (pretreatment with $\mathrm{K}_{2} \mathrm{CO}_{3}$ at 5:100 and 10:100 ratio), and $5 \mathrm{CB}$ and $10 \mathrm{CB}$ (pretreatment with $\mathrm{CaO}$ at 5:100 and 10:100 ratio), respectively.

\subsection{Chemical characterization of biochar Si and its release}

Biochar sample $\mathrm{pH}$ was measured based on 1:100 biochar to D.I. water ratio (Cantrell et al. 2011). Ash content was measured by furnace at $550{ }^{\circ} \mathrm{C}$ for $5 \mathrm{~h}$. Total $\mathrm{C}$ and $\mathrm{N}$ analyses were carried out using an elemental analyzer (Elementar Analysen systeme GmbH, Germany). Biochar total P, K, Ca, $\mathrm{Mg}, \mathrm{Cu}$ and $\mathrm{Fe}$ were determined by ICP-AES (SPECTRO Plasma 3200, Germany) after digestion with nitric acid and $\mathrm{H}_{2} \mathrm{O}_{2}$ (Huang and Schulte 1985). Total $\mathrm{Si}$ in alkali-enhanced biochars and feedstocks was determined using a $1.5 \mathrm{M}$ $\mathrm{HF}-0.6 \mathrm{M} \mathrm{HCl}$ extraction, and fertilizer soluble Si fraction in biochar samples was evaluated using 5-day sodium 
carbonate and ammonium nitrate $\left(\mathrm{Na}_{2} \mathrm{CO}_{3}-\mathrm{NH}_{4} \mathrm{NO}_{3}\right)$ extraction (referred as 5dSCAN) designated by the Association of American Plant Food Control Officials (AAPFCO) followed by light absorption spectrometry (Saito et al. 2005; Sebastian et al. 2013). Specifically, the HF-HCl extraction was performed at a 1:100 solid to solution ratio for $1 \mathrm{~h}$ with stirring every $10 \mathrm{~min}$. The $5 \mathrm{dSCAN}$ extraction procedure was carried out at a 1:1000 solid to solution ratio for $1 \mathrm{~h}$ shaking (at $140 \mathrm{rpm}$ ) followed by settling for 4 days and $23 \mathrm{~h}$. The samples were then filtered using a Whatman filter paper $(<2.5 \mu)$ before $\mathrm{Si}$ analysis.

Four additional Si test methods including $0.5 \mathrm{M} \mathrm{HCl}, 1 \mathrm{M}$ sodium acetate buffer ( $\mathrm{pH} 4.0$ ), 1-h equilibrium of $0.094 \mathrm{M}$ $\mathrm{Na}_{2} \mathrm{CO}_{3}-0.2 \mathrm{M} \mathrm{NH}_{4} \mathrm{NO}_{3}$ mixed solution (1hSCAN), and $0.5 \mathrm{M}$ ammonium acetate were also used to determine different levels of extractable Si from alkali-enhanced biochars along with commonly used mineral Si fertilizer wollastonite (WO) (W10, Vansil®, R.T. Vanderbilt Co, Norwalk, CT). Among these four methods, $0.5 \mathrm{M} \mathrm{HCl}$ is the official procedure to evaluate available $\mathrm{Si}$ from slag-based calcium silicate fertilizer in Japan (NIAES 1987; Ma and Takahashi 2002). The $1 \mathrm{M}$ acetate buffer ( $\mathrm{pH} 4.0$ ) method is widely used to evaluate available $\mathrm{Si}$ in soil as well as in slags (NIAES 1987). The method could extract soluble and some exchangeable Si (Snyder 2001), although it has been shown to over-estimate Si availability in soil amended with calcium silicate slag (Takahashi 1981) and in calcareous soils (Liang et al. 1994). The $0.5 \mathrm{M}$ ammonium acetate extraction method also extracts soluble and some exchangeable Si (Takahashi 1981; Kato and Owa 1997). The 1hSCAN extraction, the shorter version of 5dSCAN procedure, has been routinely used in Brazil (Korndorfer et al. 2004). For these four methods, the extractions were based on 1:1000 solid to solution ratio for $1 \mathrm{~h}$ of shaking at $140 \mathrm{rpm}$ followed by filtration (Hallmark et al. 1982; Wang et al. 2004).

In addition, the total $\mathrm{Si}$ released during 30 days from $\mathrm{RS}, \mathrm{RH}, \mathrm{K}_{2} \mathrm{CO}_{3}$-enhanced RS and $\mathrm{RH}$ biochars (RS$0 \mathrm{~B} / 5 \mathrm{~K} 2 \mathrm{~B} / 10 \mathrm{~K} 2 \mathrm{~B}$ and $\mathrm{RH}-0 \mathrm{~B} / 5 \mathrm{~K} 2 \mathrm{~B} / 10 \mathrm{~K} 2 \mathrm{~B}$ ) was evaluated in unbuffered weak acid solution $(0.1 \mathrm{mM} \mathrm{HCl})$ and neutral salt solution $(0.01 \mathrm{M} \mathrm{KCl})$, respectively. For comparison, wollastonite (WO) and industrial by-product silicate slag (SL) (SILI-CAL ${ }^{\mathrm{TM}}$, Calcium Silicate Corp., Lake Harbor, FL) samples were also investigated. In doing so, a series of $30-\mathrm{mg}$ samples (ground to pass a 1-mm sieve) with each mixed with $30 \mathrm{ml}$ of extractant solutions in 50-ml polyethylene centrifuge tubes were prepared. The mixtures were shaken continuously at $120 \mathrm{rpm}$ under $25.0 \pm 0.5^{\circ} \mathrm{C}$ for $1 \mathrm{~h}$, $1,5,9,14,21$ and 30 days, respectively. The samples were then filtered using Whatman filter paper $(<2.5 \mu \mathrm{m})$ before analysis.

The $\mathrm{Si}$ in all the filtrates was determined using a SPECTRONIC 501 light absorption spectrophotometer (Thermo Scientific, Wilmington, DE) following blue silicomolybdous acid procedures (Hallmark et al. 1982; Wang et al. 2004; Sebastian et al. 2013). The spectrometer was calibrated using a standard curve for each extraction method before sample analysis. For all analytical procedures, duplicate samples were measured and a spike recovery of $95 \%$ of a known Si standard in selected samples was performed for quality control of analytical process.

\subsection{Rice greenhouse potting study}

A potting experiment using rice (Oryza sativa $\mathrm{L}$ ) was conducted to assess plant response to the produced biochar $\mathrm{Si}$ source in the greenhouse at Louisiana State University, Baton Rouge, USA. The soil used in potting study was Crowley silt loam (fine-silty, montmorillonitic, thermic Typic Albaqualf) with $\mathrm{pH}$ 7.6, and its Mehlich-III soil-test extractable $\mathrm{P}$ and $\mathrm{K}$ were 10 and $69 \mathrm{mg} \mathrm{kg}^{-1}$, respectively. Twelve types of Si sources including RS, RH, four alkalienhanced RS biochars produced at 350 and $550{ }^{\circ} \mathrm{C}$ (RS0B-350, RS-10K2B-350, RS-0B-550, RS-10K2B-550), four alkali-enhanced $\mathrm{RH}$ biochars produced at 350 and $550^{\circ} \mathrm{C}$ (RH-0B-350, RH-10K2B-350, RH-0B-550, RH10K2B-550), WO, SL along with a control (CK) without addition of amendment were used. Each Si source was applied at the rate $0.22 \%$ on soil mass basis (equivalent to $\left.5 \mathrm{t} \mathrm{ha}^{-1}\right)$. All pots received a blanket application of $\mathrm{N}$ $0.0357 \mathrm{~g} \mathrm{~kg}^{-1}\left(80 \mathrm{~kg} \mathrm{~N} \mathrm{ha}^{-1}\right), \mathrm{P}_{2} \mathrm{O}_{5} 0.0302 \mathrm{~g} \mathrm{~kg}^{-1}(68 \mathrm{~kg}$ $\mathrm{P}_{2} \mathrm{O}_{5}$ ha $\left.^{-1}\right)$, and $\mathrm{K}_{2} \mathrm{O} 0.0302 \mathrm{~g} \mathrm{~kg}^{-1}\left(68 \mathrm{~kg} \mathrm{~K}_{2} \mathrm{O} \mathrm{ha}^{-1}\right)$ before planting. Two rice seeds were sown in a $12-\mathrm{cm}$ diameter plastic pot. A second $\mathrm{N}$ application of $0.025 \mathrm{~g} \mathrm{~kg}^{-1}(56 \mathrm{~kg}$ $\mathrm{ha}^{-1}$ ) was made to each pot after three weeks, and then the pot was flooded. Rice plants were harvested after 23 weeks of growth in the pots. Rice grain (husk and seed) and straw (stem and blade) were washed with deionized water and dried at $60{ }^{\circ} \mathrm{C}$ for $48 \mathrm{~h}$. Plant Si content was analyzed by extracting the tissue with $1.5 \mathrm{M} \mathrm{HF}-0.6 \mathrm{M} \mathrm{HCl}$, followed by detection using light absorption spectrometry (Saito et al. 2005; Sebastian et al. 2013). All treatments were replicated three times.

All statistical analyses were carried out using the Statistical Analysis Software, version 9.0 (SAS Institute, Cary, NC). Average results for the different treatments were compared using analysis of variance.

\section{Results}

\subsection{Chemical and physical properties of alkali-enhanced biochars at different preparation temperatures}

In general, biochar yield was reduced with increasing pyrolysis temperature in all alkali-enhanced biochars (Tables S1 and 
$\mathrm{S} 2)$. The $\mathrm{pH}$ and ash content of alkali-enhanced rice straw and husk biochars increased with increasing pyrolysis temperature (Tables S1 and S2). Specifically, the $\mathrm{pH}$ of $350^{\circ} \mathrm{C}$ prepared RS-0B and RH-0B were $6.46 \sim 6.65,450$ and $550{ }^{\circ} \mathrm{C}$ treatments increased the $\mathrm{pH}$ of $\mathrm{OB}$ by $1.53 \sim 2.24$ and $2.12 \sim 2.95$ unit, respectively. As the proportion of $\mathrm{KOH}, \mathrm{K}_{2} \mathrm{CO}_{3}$ and $\mathrm{CaO}$ increased, $\mathrm{pH}$ of biochars increased correspondingly. From 350 to $550{ }^{\circ} \mathrm{C}$, ash contents of RS-0B and RH-0B increased from 32 and $34 \%$ to 45 and $44 \%$, respectively. After alkali pretreatment, ash contents of $550{ }^{\circ} \mathrm{C}$ prepared rice straw- and husk-derived 10KB, 10K2B and 10CB were increased by $8 \sim 28 \%, 9 \sim 12 \%$ and $16 \sim 24 \%$, respectively, as compared to non-enhanced 0B samples. Ash contents of $350{ }^{\circ} \mathrm{C}$ prepared biochars showed the similar trend.

The carbon content of both RS-0B and RH-OB biochar samples increased with increasing temperature while $\mathrm{C}$ and $\mathrm{N}$ contents decreased as alkali proportion increased (Tables $\mathrm{S} 1$ and S2). At $550{ }^{\circ} \mathrm{C}, \mathrm{C}$ contents of $550{ }^{\circ} \mathrm{C}$ prepared RSand RH-10KB, 10K2B, 10CB decreased by 22 24\%, $7 \sim 11 \%$, and $27 \sim 45 \%$, respectively, comparing to $0 \mathrm{~B}$ biochar samples. Increasing pyrolysis temperature also generally increased total $\mathrm{P}, \mathrm{K}, \mathrm{Ca}$ and $\mathrm{Mg}$ contents of RS and RH biochars, although they reached maximum concentrations at different temperature. As expected, biochar total $\mathrm{K}$ and $\mathrm{Ca}$ contents increased with increasing alkali amendment ratio of $\mathrm{KOH}, \mathrm{K}_{2} \mathrm{CO}_{3}$ and $\mathrm{CaO}$, respectively. Overall, all three alkali pretreatments affected the elemental composition of prepared biochars at different pyrolysis temperatures.

\subsection{Total Si content of alkali-enhanced biochar at different preparation temperatures}

Total Si in the alkali-enhanced biochar changed with biomass feedstock, pyrolysis temperature, and type and proportion of alkali pretreatment (Fig. 1). For OB samples, total $\mathrm{Si}$ was maximized at $450{ }^{\circ} \mathrm{C}$ for rice straw and at $550{ }^{\circ} \mathrm{C}$ for rice husk. Increasing alkali pretreatment proportion tended to decrease total Si content in biochar samples with $\mathrm{KOH}, \mathrm{K}_{2} \mathrm{CO}_{3}$ and $\mathrm{CaO}$ pretreatment. On the other hand, for the rice straw biochar, total Si content of $10 \mathrm{~KB}$ prepared at $350{ }^{\circ} \mathrm{C}$ was $21.8 \%$ and decreased to $18.9 \%$ with increasing temperature. When pyrolysis temperature was raised to $550{ }^{\circ} \mathrm{C}$, total $\mathrm{Si}$ content of $10 \mathrm{CB}$ was $64 \%$ higher than that of rice straw biochar prepared at $350{ }^{\circ} \mathrm{C}$ (Fig. 1A). A similar trend was also observed for rice husk biochars, although $0 \mathrm{~B}$ samples had generally higher total Si compared to that of rice straw biochars (Fig. 1B), emphasizing the impact of the feedstock.

\subsection{5dSCAN-extractable Si content of alkali-enhanced biochar at different preparation temperatures}

Extractable Si evaluation of produced biochar Si sources using the designated $5 \mathrm{dSCAN}$ method by AAPFCO (Sebastian et al. 2013) for fertilizer $\mathrm{Si}$ is presented in Fig. 2. Although total Si was higher in rice husk biochar (Fig. 1), rice straw biochar showed generally higher 5dSCAN-Si (Fig. 2). For all pyrolysis temperatures, 5dSCAN-Si content of non-enhanced $0 \mathrm{~B}$ samples, regardless of feedstock source, was higher than that of the feedstock sample. The non-enhanced $\mathrm{OB}$ samples prepared at $350^{\circ} \mathrm{C}$ exhibited the maximum $\mathrm{Si}$ content, but it decreased with pyrolysis temperature (Fig. 2). For biochar samples, increasing pyrolysis temperature generally shifted the $5 \mathrm{dSCAN}-\mathrm{Si}$ concentration higher at $550{ }^{\circ} \mathrm{C}$, particularly in biochars with greater alkali pretreatment. For example, in the $\mathrm{KOH}$-enhanced rice straw biochar, the $10 \mathrm{~KB}$ prepared at $550{ }^{\circ} \mathrm{C}$ yielded 5dSCAN-Si content of $4.67 \%$, which was significantly higher than the $10 \mathrm{~KB}$ prepared at 350 and $450{ }^{\circ} \mathrm{C}$ by 110 and $61 \%$, respectively. The 5dSCAN-Si content of the 10K2B and 10CB treatments prepared at $550{ }^{\circ} \mathrm{C}$ was also 61 and $62 \%$ higher than that of those prepared at $350{ }^{\circ} \mathrm{C}$ (Fig. 2A). A similar trend was seen for the rice husk biochars (Fig. 2B). Interestingly, the extractable Si content of non-enhanced rice husk $0 \mathrm{~B}$ by $5 \mathrm{dSCAN}$ method was less than that of rice straw $\mathrm{OB}$ samples. In addition, the 5dSCAN-Si content of biochars pretreated with $\mathrm{KOH}$ and $\mathrm{K}_{2} \mathrm{CO}_{3}$ increased significantly with increasing pyrolysis temperature; however, the 5dSCAN-Si content of 5CB and 10CB biochars pretreated with $\mathrm{CaO}$ remained relatively stable.

Figure 3 shows the comparison of extractable Si level in alkali-enhanced biochar sources by four additional extraction methods. Since high alkali pretreatment yielded higher Si extractability, only $10 \mathrm{~KB}, 10 \mathrm{~K} 2 \mathrm{~B}$, and $10 \mathrm{CB}$ were selected in this comparison along with feedstock, $0 \mathrm{~B}$ and wollastonite (WO), which was used as a standard Si fertilizer. The $0.5 \mathrm{M} \mathrm{HCl}$ method extracted significantly more Si from wollastonite than that from biochars produced at all three pyrolysis temperatures, regardless of which biomass feedstocks were used. On the other hand, the 1hSCAN method extracted significantly more Si from alkali-enhanced biochars made from both feedstocks, especially rice straw, than that from wollastonite. The $1 \mathrm{hSCAN}$ method yielded equivalent or even more extractable Si from alkali-enhanced biochars made at 350 and $550{ }^{\circ} \mathrm{C}$ than that from the $0.5 \mathrm{M}$ 

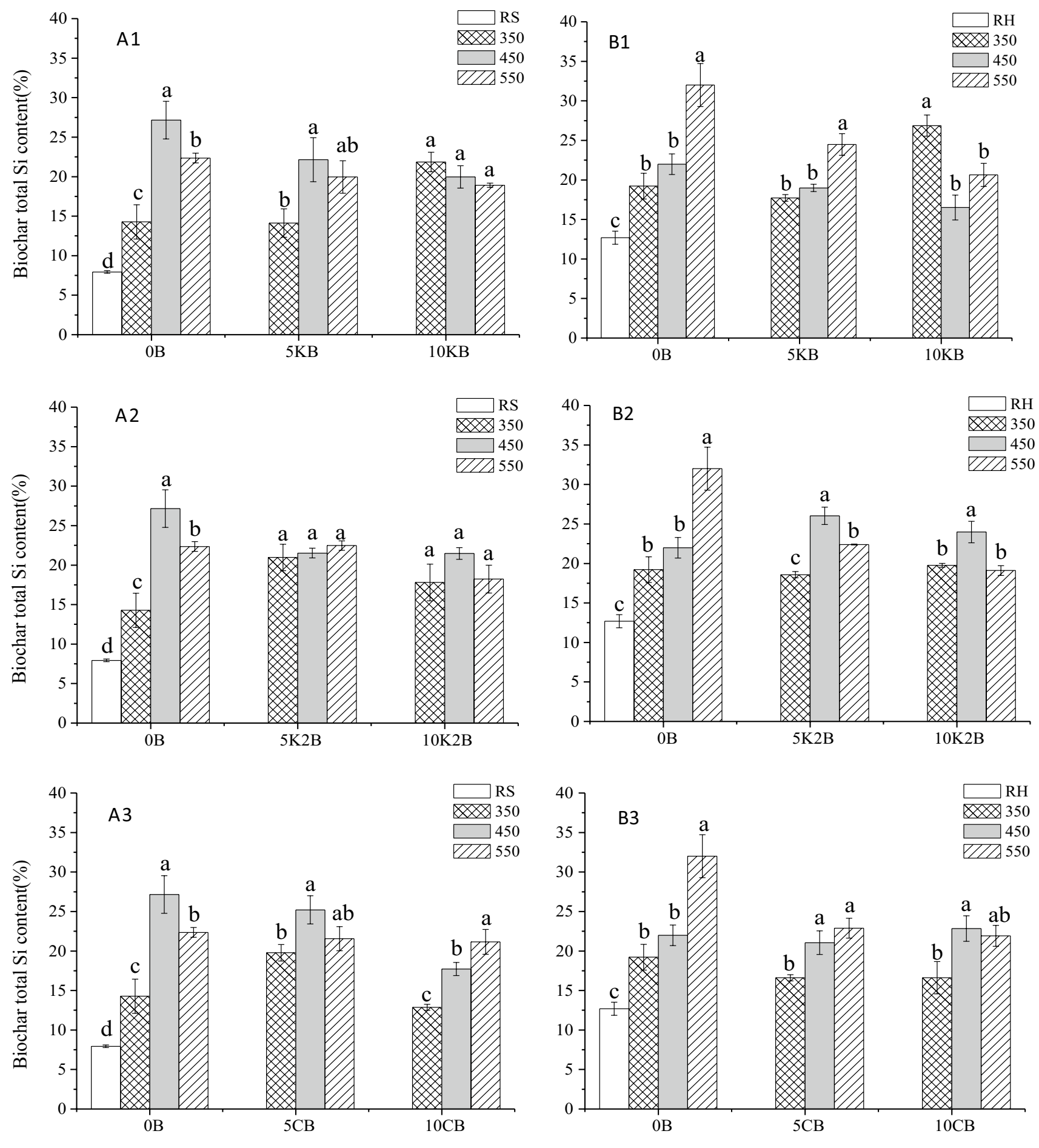

Treatment

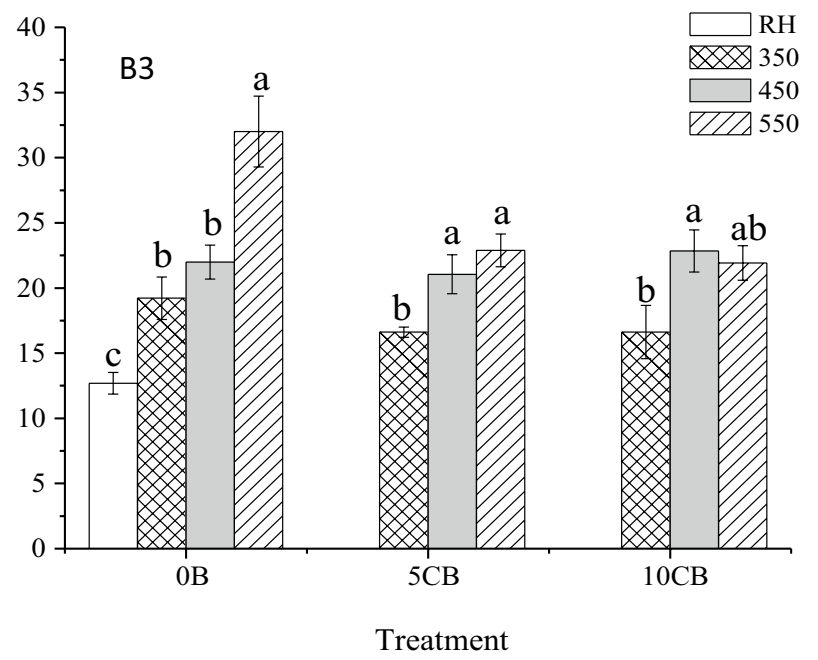

Fig. 1 Total Si contents of (A) rice straw biochar and (B) rice husk biochar prepared at different pyrolysis temperatures. Subgraphs $\mathrm{A} 1$ and $\mathrm{B} 1, \mathrm{~A} 2$ and $\mathrm{B} 2, \mathrm{~A} 3$ and $\mathrm{B} 3$ indicate alkali treatments with $\mathrm{KOH}, \mathrm{K}_{2} \mathrm{CO}_{3}$, or $\mathrm{CaO}$, respectively; RS, rice straw; $\mathrm{RH}$, rice husk; $0 \mathrm{~B}, 5 \mathrm{~KB} / 5 \mathrm{~K} 2 \mathrm{~B} / 5 \mathrm{CB}, 10 \mathrm{~KB} / 10 \mathrm{~K} 2 \mathrm{~B} / 10 \mathrm{CB}$ indicate the biochars pre-

pared at the proportion of $\mathrm{KOH} / \mathrm{K}_{2} \mathrm{CO}_{3} / \mathrm{CaO}$ to feedstock of $0: 100$, $5: 100,10: 100$. The $350,450,550{ }^{\circ} \mathrm{C}$ indicate pyrolysis temperatures. Different letters indicate significant differences within treatments $(P<0.05)$. The error bar indicates plus and minus of one standard deviation 

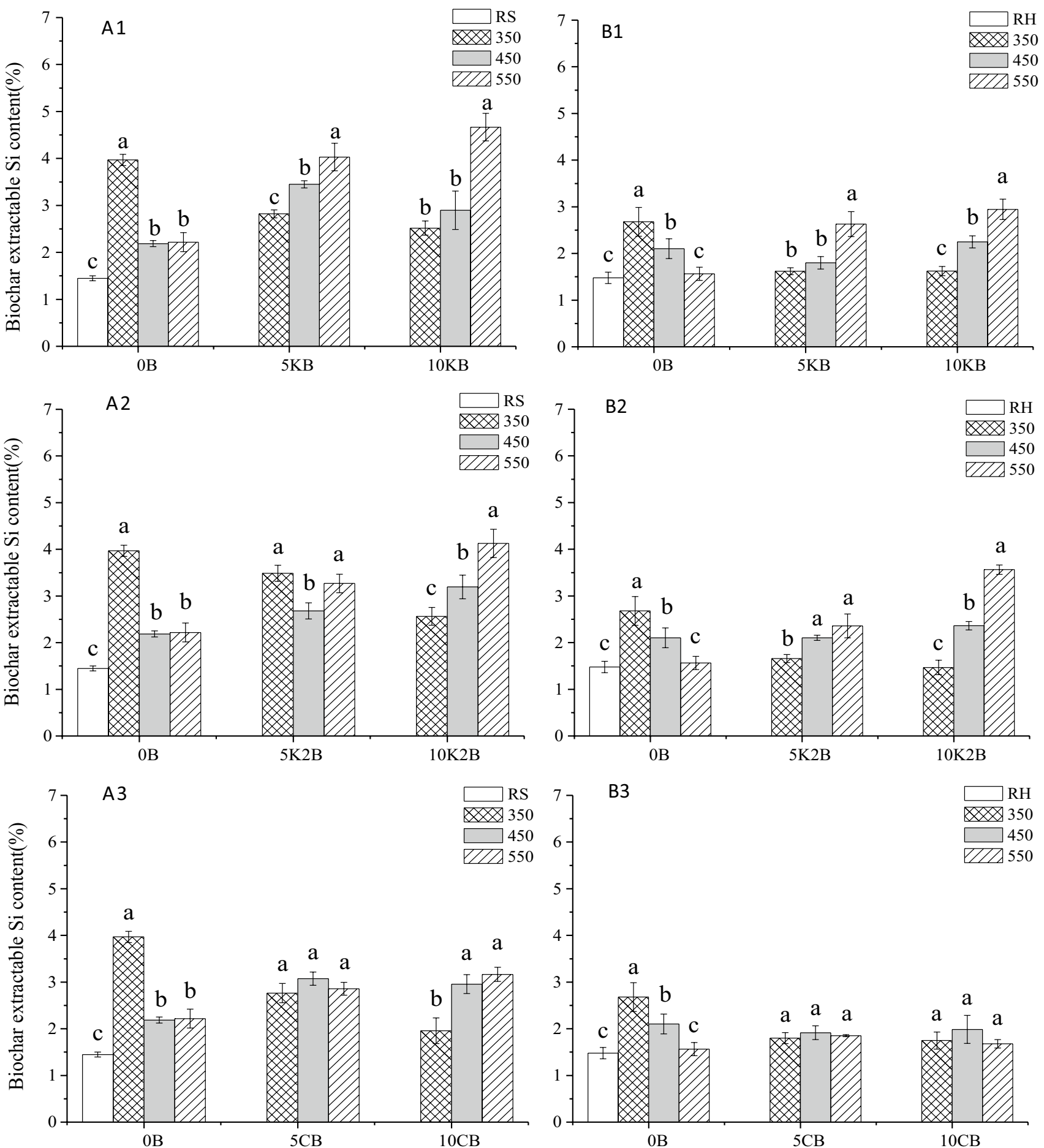

Treatment

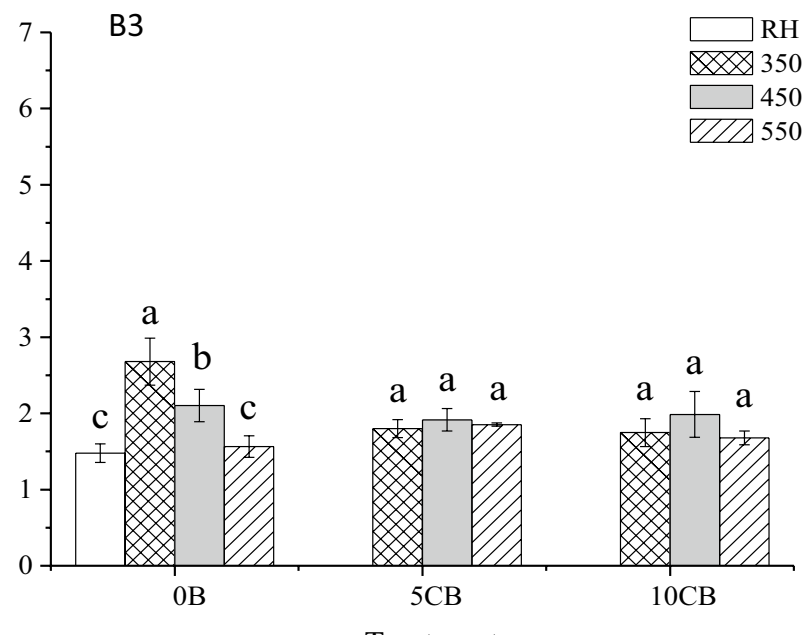

Fig. 2 Comparison of 5dSCAN-extractable $\mathrm{Si}$ contents of alkalienhanced (A) rice straw and (B) rice husk biochars prepared at different pyrolysis temperatures. Subgraphs A1 and B1, A2 and B2, $\mathrm{A} 3$ and $\mathrm{B} 3$ indicate alkali treatments with $\mathrm{KOH}, \mathrm{K}_{2} \mathrm{CO}_{3}$, or $\mathrm{CaO}$, respectively; $\mathrm{RS}$, rice straw; $\mathrm{RH}$, rice husk; $0 \mathrm{~B}, 5 \mathrm{~KB} / 5 \mathrm{~K} 2 \mathrm{~B} / 5 \mathrm{CB}$,

$10 \mathrm{~KB} / 10 \mathrm{~K} 2 \mathrm{~B} / 10 \mathrm{CB}$ indicate the biochars prepared at the proportion of $\mathrm{KOH} / \mathrm{K}_{2} \mathrm{CO}_{3} / \mathrm{CaO}$ to feedstock of $0: 100,5: 100,10: 100$. The 350, $450,550{ }^{\circ} \mathrm{C}$ indicate pyrolysis temperatures. Different letters indicate significant differences within treatment $(P<0.05)$. The error bar indicates plus and minus of one standard deviation 

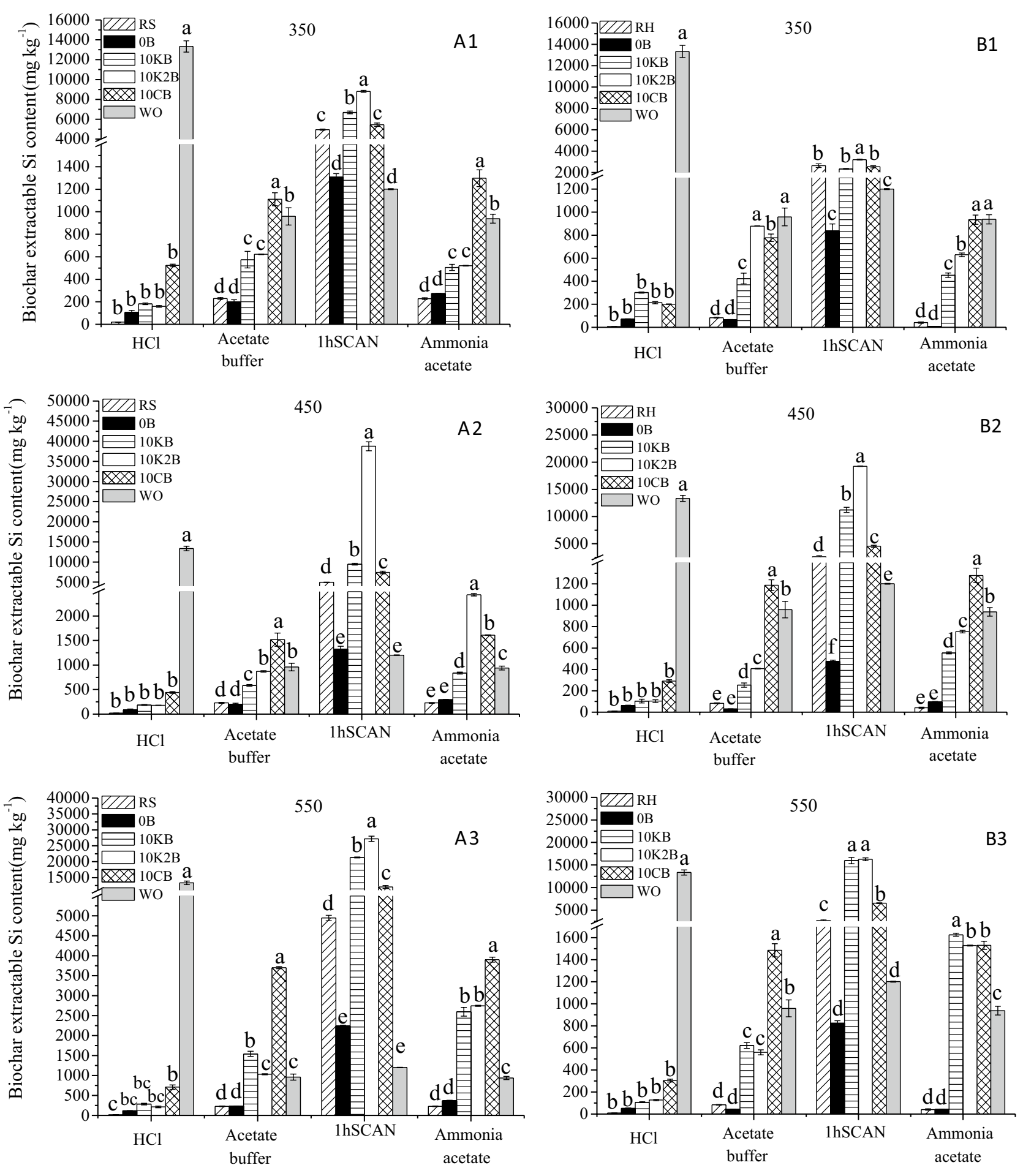

Extration method

Extraction method

Fig. 3 Alkali-enhanced (A) rice straw and (B) husk biochar extractable Si extracted from four routine extraction methods. Subgraphs $\mathrm{A} 1$ and $\mathrm{B} 1, \mathrm{~A} 2$ and $\mathrm{B} 2, \mathrm{~A} 3$ and $\mathrm{B} 3$ indicate pyrolysis temperatures of $350,450,550{ }^{\circ} \mathrm{C}$, respectively; $\mathrm{RS}$, rice straw; $\mathrm{RH}$, rice husk; $0 \mathrm{~B}$, $10 \mathrm{~KB} / 10 \mathrm{~K} 2 \mathrm{~B} / 10 \mathrm{CB}$ indicate the biochars prepared at the proportion of $\mathrm{KOH} / \mathrm{K}_{2} \mathrm{CO}_{3} / \mathrm{CaO}$ to feedstock of $0: 100$, 10:100; $W O$ wollastonite. Different letters indicate significant differences within treatment $(P<0.05)$. The error bar indicates plus and minus of one standard deviation 
$\mathrm{HCl}$ extraction of wollastonite (Fig. 3). This was particularly evident for the $10 \mathrm{~K} 2 \mathrm{~B}, 10 \mathrm{~KB}$, and $10 \mathrm{CB}$ treatments prepared at $550{ }^{\circ} \mathrm{C}$, which showed the increase of $1 \mathrm{hSCAN}-\mathrm{Si}$ content of 2163,1675 , and $903 \%$ higher than wollastonite, respectively. Furthermore, both $1 \mathrm{M}$ sodium acetate buffer and $0.5 \mathrm{M}$ ammonium acetate methods generally extracted less Si compared to the 1hSCAN extraction procedure but they extracted more Si from alkali-enhanced biochars than that from wollastonite as well as from non-enhanced $0 \mathrm{~B}$ samples. These four additional test methods also showed that alkali-enhanced biochars tended to have greater extractable Si concentrations when produced at higher pyrolysis temperatures, and extractable Si concentrations were generally significantly higher than those of non-enhanced $0 \mathrm{~B}$ biochars. Overall, these methods measure various fractions of extractable Si from different Si sources. Nonetheless, it was found that the Si fraction extracted by $0.5 \mathrm{M} \mathrm{HCl}$ was closely related to that extracted by the buffered sodium acetate $(\mathrm{pH}$ 4.0) $(r=0.967, P<0.01)$, whereas the 1hSCAN extraction method was related to $0.5 \mathrm{M}$ ammonium acetate method $(r=0.978, P<0.01)$. The $1 \mathrm{~h}$ and 5 day $\mathrm{Na}_{2} \mathrm{CO}_{3}-\mathrm{NH}_{4} \mathrm{NO}_{3}$ methods were only weakly related $(r=0.626, P<0.05)$.

\subsection{Si release from alkali-enhanced biochar prepared at different pyrolysis temperatures}

Total Si released over 30 days from biochar prepared at different temperatures in unbuffered weak acid $(0.1 \mathrm{mM} \mathrm{HCl}$, $\mathrm{pH} 4.0)$ and neutral salt $(0.01 \mathrm{M} \mathrm{KCl}$, initially adjusted to $\mathrm{pH}$ 7.0) solutions are shown in Figs. 4 and 5, respectively. Since both total $\mathrm{Si}$ and $5 \mathrm{dSCAN}-\mathrm{Si}$ contents of biochars were similar between $\mathrm{KOH}$ and $\mathrm{K}_{2} \mathrm{CO}_{3}$ pretreatments and were generally greater than those of the $\mathrm{CaO}$ pretreatment, only $\mathrm{K}_{2} \mathrm{CO}_{3}$-enhanced rice straw biochars were selected for this evaluation. In this assessment, the alkali-enhanced biochar was compared with 0B (non-enhanced), feedstock (RS) as well as with wollastonite and silica slag. For both acid and neutral salt solutions, the 10K2B biochar showed the greatest cumulative $\mathrm{Si}$ release, followed by $5 \mathrm{~K} 2 \mathrm{~B}$ biochar. The $\mathrm{Si}$ release from the both was higher than that from the $\mathrm{OB}$ biochar as well as that from the raw feedstock, wollastonite and silica slag over the 30-day incubation. The 30-day cumulative $\mathrm{Si}$ release in the unbuffered weak acid and neutral salt solutions was highly correlated $(r=0.927, P<0.05$ for rice straw biochars and $r=0.995, P<0.01$ for husk biochars, respectively). A higher pyrolysis temperature generally led to greater $\mathrm{Si}$ release, with 450 and $550{ }^{\circ} \mathrm{C}$-prepared biochars yielding greater Si release than $350^{\circ} \mathrm{C}$ prepared biochar.

The Si release characteristics suggested that these samples could be divided into three groups: (1) the RS, WO and SL group that released the least Si over 30 days and for which Si release curves were close to each other or mostly overlapped, (2) the $\mathrm{K}_{2} \mathrm{CO}_{3}$-enhanced biochar (5K2B and
10K2B) group, which showed a rapid Si release during the first 2 days, continued to release gradually with time and had the greatest Si release among all treatments, and (3) the OB biochars, which yielded $\mathrm{Si}$ release curves between those of the other two groups. It is interesting to note that the $\mathrm{Si}$ release curves and the cumulative release from the rice straw 0B biochars were closer to those of the $\mathrm{K}_{2} \mathrm{CO}_{3}$-enhanced biochars for rice straw feedstock (Figs. $4 \mathrm{~A}$ and $5 \mathrm{~A}$ ), while the rice husk $0 \mathrm{~B}$ samples were not to their $\mathrm{K}_{2} \mathrm{CO}_{3}$-enhanced biochars for rice husk (Figs. 4B and 5B), indicating a difference in the nature of Si release between the two biochar feedstocks in responding to alkali pretreatment.

\subsection{Effect of alkali-enhanced biochar application on rice Si uptake and yield}

Rice growth in soils treated with alkali-enhanced biochars along with non-enhanced biochar (0B) produced at different temperatures was evaluated in a greenhouse potting study, and the results are presented in Figs. 6 and 7. Based on the amount of Si extracted by different chemical methods and the cumulative Si release studies (Figs. 2, 3, 4 and 5), the potting trial focused only on a comparison of $\mathrm{K}_{2} \mathrm{CO}_{3}$-enhanced biochar with non-enhanced $0 \mathrm{~B}$ biochar, wollastonite, and silica slag. Application of biochars significantly increased the $\mathrm{Si}$ content of rice straw compared to that of the control (CK) treatment. The Si uptake under the treatments of rice straw biochars, RS-10K2B-350 and RS-10K2B-550, was 31 and 29\% higher than that of the control treatment, respectively (Fig. 6A). The Si uptake under the treatment of rice husk biochar RH-10K2B-550 was the highest among all Si treatments and was significantly higher than wollastonite and calcium silicate slag by 34 and $24 \%$, respectively (Fig. 6B). In addition, for the rice husk-derived biochar treatments, the Si uptake contents in straw associated with the RH-0B-550 and RH-10K2B-550 treatments were significantly higher than those of the corresponding $\mathrm{RH}-0 \mathrm{~B}-350$ and $\mathrm{RH}-10 \mathrm{~K} 2 \mathrm{~B}-350$ treatments by 9 and 33\%, respectively. These results indicated that alkali-enhanced biochar Si sources prepared at high pyrolysis temperatures tended to promote higher Si uptake by rice straw, particularly in the case of the rice husk-derived biochar products. Furthermore, the alkali-enhanced biochar $\mathrm{Si}$ sources also increased rice grain yields. Applications of both RS- and RH-10K2B-550 biochars produced significantly higher rice grain yields than those of nonenhanced RS- and RH-0B-350 biochars (Fig. 7). The RH10K2B-550 application had significantly higher rice yield than the RH-0B-550 treatment, while RS-10K2B-550 had greater yield than RS-0B-550 (Fig. 7). In addition, RH$10 \mathrm{~K} 2 \mathrm{~B}-350$ treatment led to a rice yield that was numerically higher than the yield of the RH-0B-350 treatment. Rice yield associated with the RH-10K2B-550 treatment 

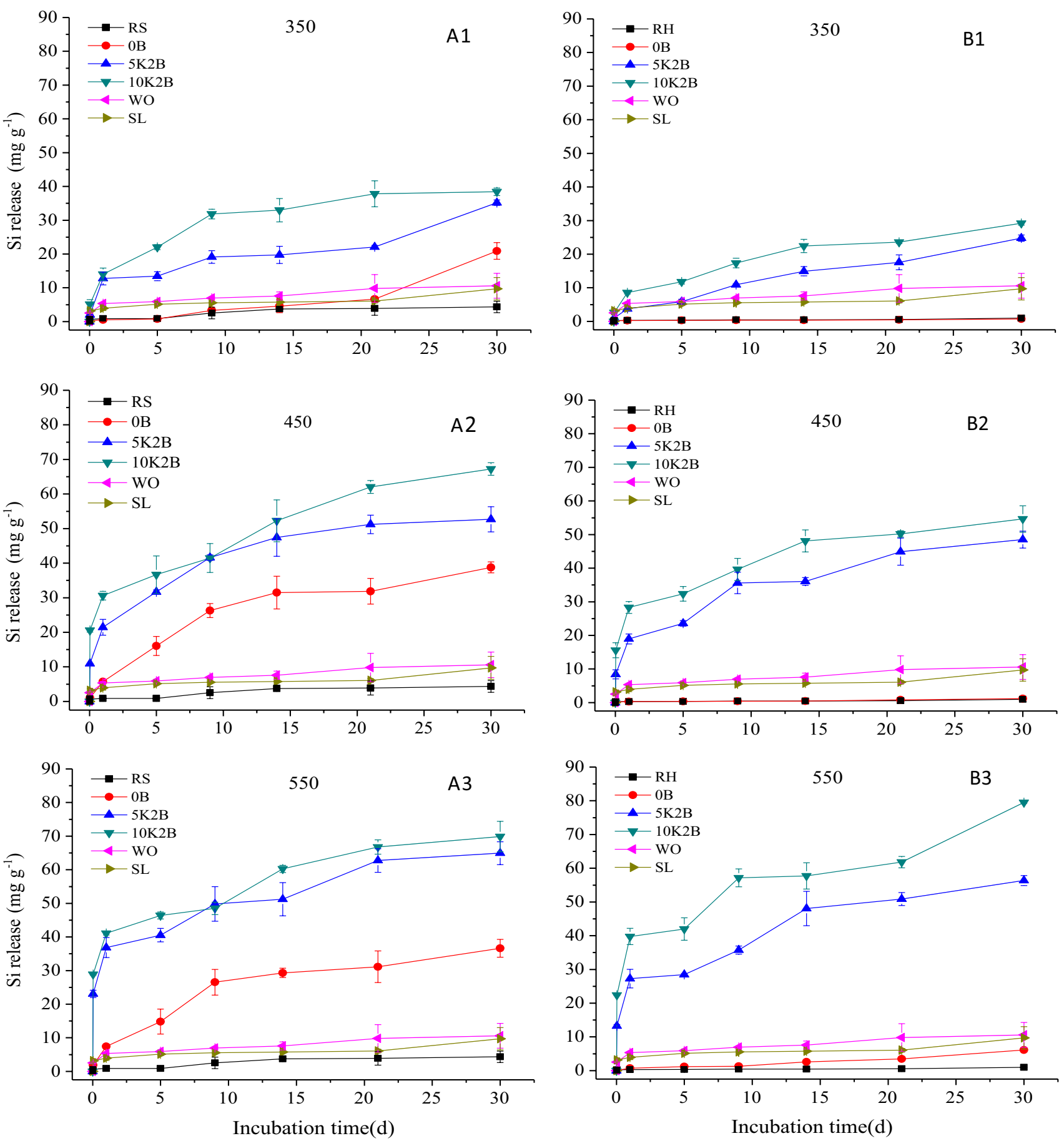

Fig. $4 \mathrm{Si}$ release of $\mathrm{K}_{2} \mathrm{CO}_{3}$-enhanced (A) rice straw and (B) rice husk biochars over 30 days in unbuffered weak acid $(0.1 \mathrm{mM} \mathrm{HCl})$ solutions. Subgraphs A1 and B1, A2 and B2, A3 and B3 indicate pyrolysis temperatures of $350,450,550{ }^{\circ} \mathrm{C}$, respectively. RS, rice straw;

was even significantly greater than that of wollastonite and silica slag amendments. Grain yield was significantly correlated with Si uptake in rice straw $(r=0.808$, $P<0.01)$ for biochar $\mathrm{Si}$ sources of RS/RH-0B-350/550 and RS/RH-10K2B-350/550 treatments (Fig. S2). These

$\mathrm{RH}$, rice husk; $0 \mathrm{~B}, 5 \mathrm{~K} 2 \mathrm{~B}$ and $10 \mathrm{~K} 2 \mathrm{~B}$ indicate the biochars prepared at the proportion of $\mathrm{K}_{2} \mathrm{CO}_{3}$ to feedstock of 0:100, 5:100 and 10:100; $W O$ wollastonite, $S L$ calcium silicate slag. The error bar indicates plus and minus of one standard deviation

results indicate that both pyrolysis temperature and alkalipretreatment are important in producing biochar-based Si fertilizer source. These results were consistent with greater cumulative dissolution of $\mathrm{Si}$ in both weak acid and unbuffered neutral salt solutions from the alkali-enhanced 

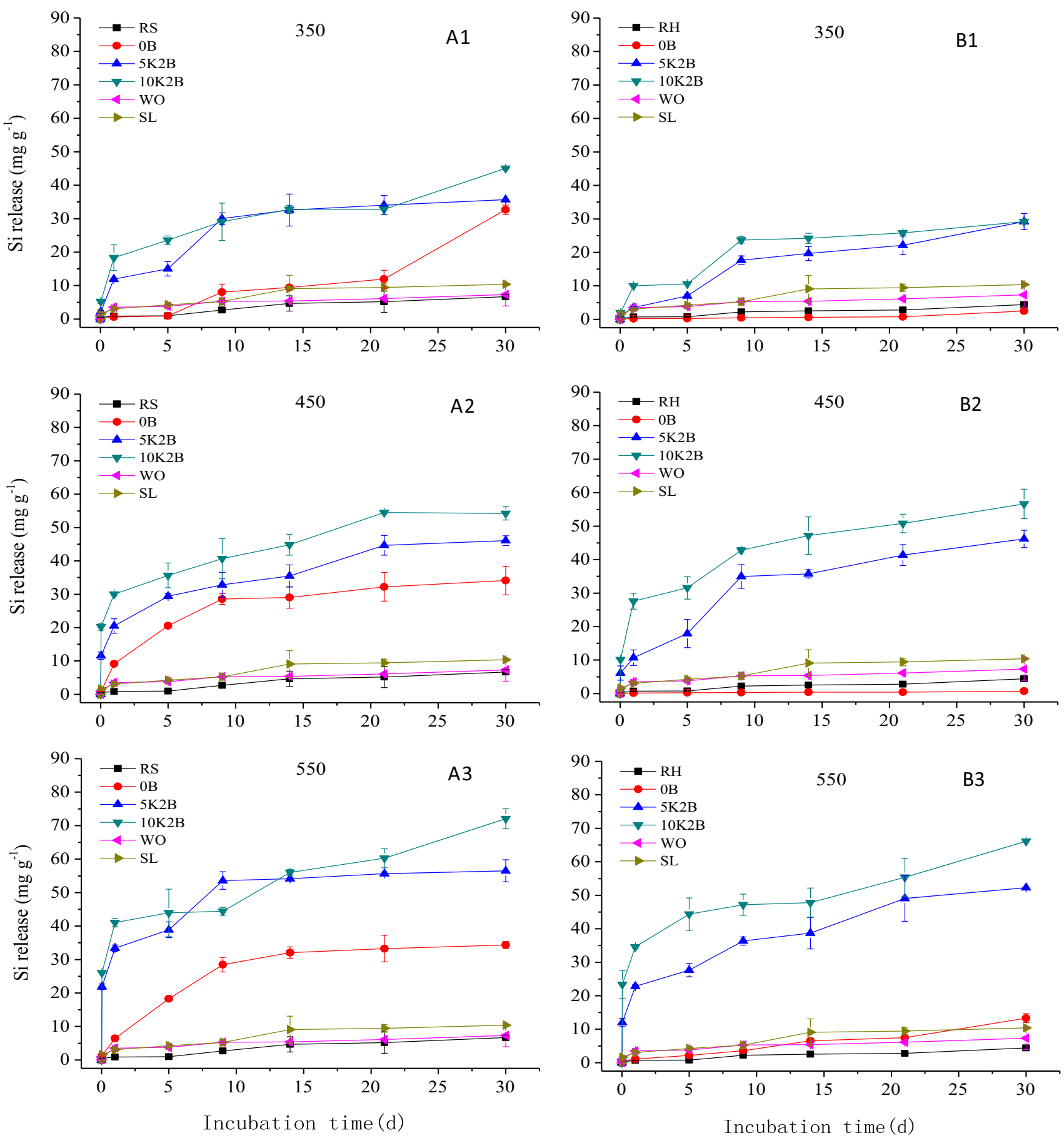

Fig. 5 Si release of $\mathrm{K}_{2} \mathrm{CO}_{3}$-enhanced (A) rice straw and (B) rice husk

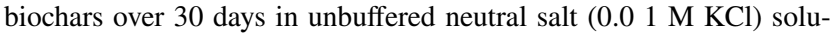
tions. Subgraphs A1 and B1, A2 and B2, A3 and B3 indicate pyrolysis temperatures of $350,450,550{ }^{\circ} \mathrm{C}$, RS, rice straw; $\mathrm{RH}$, rice husk;

$0 \mathrm{~B}, 5 \mathrm{~K} 2 \mathrm{~B}$ and $10 \mathrm{~K} 2 \mathrm{~B}$ indicate the biochars prepared at the proportion of $\mathrm{K}_{2} \mathrm{CO}_{3}$ to feedstock of 0:100, 5:100 and 10:100; WO wollastonite, $S L$ calcium silicate slag. The error bar indicates plus and minus of one standard deviation

10K2B biochar produced at $550{ }^{\circ} \mathrm{C}$ (Figs. 4 and 5). Rice grain yield was closely related to cumulative $\mathrm{Si}$ release over 30 days $(Y=0.0072 X+0.724, r=0.924, P<0.01$ for release in weak acid and $Y=0.0091 X+0.671, r=0.890$, $P<0.01$ in unbuffered neutral solution) (Please see supplementary Figs. S3 and S4). 

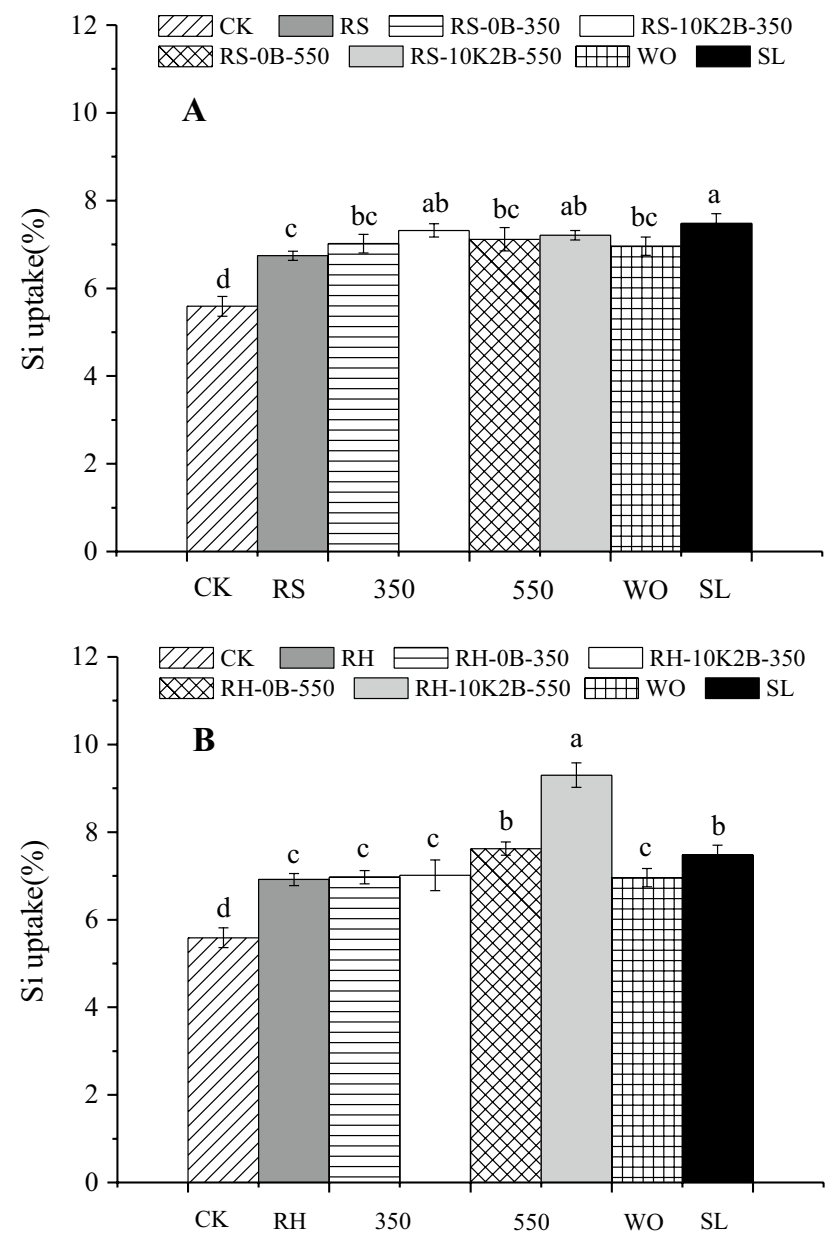

Fig. 6 Rice Si uptake with alkali-enhanced (A) rice straw biochar and (B) rice husk biochar amendments. $\mathrm{CK}$, no amendment; RS/RH, rice straw/husk; RS/RH-0B-350 and RS/RH-10K2B-350 are rice straw and husk biochars prepared with the proportion of $\mathrm{K}_{2} \mathrm{CO}_{3}$ to feedstock at 0 and 10 at $350{ }^{\circ} \mathrm{C}$, respectively; RS/RH-0B-550 and RS/ $\mathrm{RH}-10 \mathrm{~K} 2 \mathrm{~B}-550$ are rice straw biochars prepared with the proportion of $\mathrm{K}_{2} \mathrm{CO}_{3}$ to feedstock at 0 and 10 at $550{ }^{\circ} \mathrm{C}$, respectively; $W O$ wollastonite, $S L$ silicate calcium slag. The error bar indicates plus and minus of one standard deviation

\section{Discussion}

\subsection{Effect of pyrolysis temperature and alkali treatment on biochar chemical and physical properties}

As pyrolysis temperature increased from 350 to $550{ }^{\circ} \mathrm{C}$, the yield of both non-enhanced (0B) and alkali-enhanced biochars from rice straw and husk sharply decreased (Tables $\mathrm{S} 1$ and S2), due to increasing decomposition of lignocellulosic materials in biomass (Paris et al. 2005). This result is similar to studies of wood, rice husk and sugarcane bagasse biochars produced at different pyrolysis temperatures (Kim et al. 2012; Keiluweit et al. 2010; Jeong et al. 2016; Suliman et al.
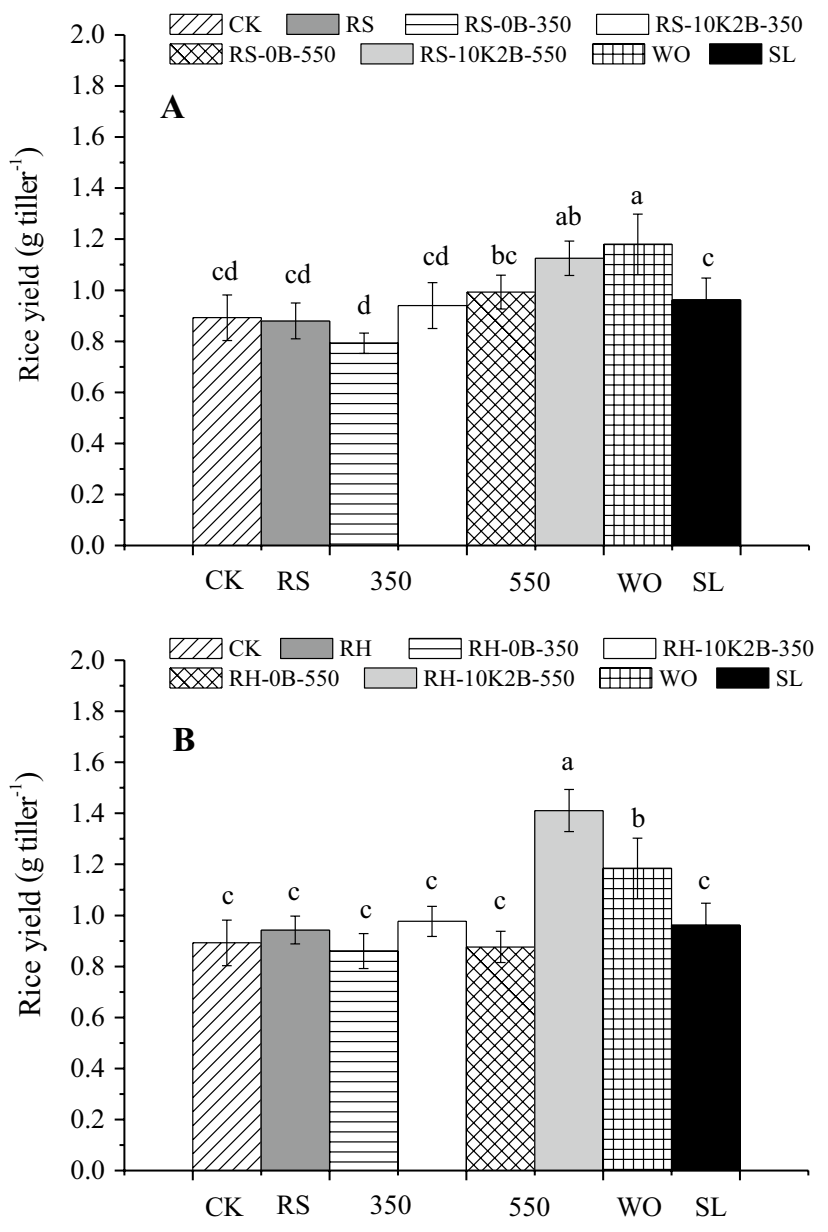

Fig. 7 Rice yield with alkali-enhanced (A) rice straw biochar and (B) rice husk biochar amendments. $\mathrm{CK}$, non-amendment; $\mathrm{RS} / \mathrm{RH}$, rice straw/husk; RS/RH-0B-350 and RS/RH-10K2B-350 are rice straw and husk biochars prepared with the proportion of $\mathrm{K}_{2} \mathrm{CO}_{3}$ to feedstock at 0 and 10 at $350{ }^{\circ} \mathrm{C}$, respectively; RS/RH-0B-550 and RS/ $\mathrm{RH}-10 \mathrm{~K} 2 \mathrm{~B}-550$ are rice straw biochars prepared with the proportion of $\mathrm{K}_{2} \mathrm{CO}_{3}$ to feedstock at 0 and 10 at $550{ }^{\circ} \mathrm{C}$, respectively; $W O$ wollastonite, $S L$ silicate calcium slag. The error bar indicates plus and minus of one standard deviation

2016; Nwajiaku et al. 2018). In addition, alkali-enhanced biochars from both rice straw and rice husk increased the $\mathrm{pH}$ and ash content as pyrolysis temperature increased from 350 to $550{ }^{\circ} \mathrm{C}$, consistent with non-enhanced biochar (0B). The latter was attributed to the conversion of alkali and alkaline earth cations $(\mathrm{Ca}, \mathrm{Mg}, \mathrm{K}, \mathrm{Na})$ to alkaline substances such as oxides, hydroxides, chlorides, and carbonates and the loss of acidic functional groups (Novak et al. 2009; Van Zwieten et al. 2010; Ahmad et al. 2012). Higher ash content was generally observed with alkali pretreatment of larger proportion of $\mathrm{KOH}, \mathrm{K}_{2} \mathrm{CO}_{3}$ and $\mathrm{CaO}$. On the other hand, the effect of pyrolysis temperature on the $\mathrm{C}$ content of alkali-enhanced biochar was less consistent, although $\mathrm{C}$ concentration in the non-enhanced biochar (0B) generally increased, which has been widely reported along with increase in concentrations 
of inorganic elements (Novak et al. 2009; Laird 2008; Jeong et al. 2016). The increase in alkali pretreatment proportion generally decreased biochar $\mathrm{C}$ content. Between 350 and $450{ }^{\circ} \mathrm{C}$ pyrolysis temperature, alkali pretreatment showed inconsistent changes in biochar $\mathrm{C}$ content. However, at $550{ }^{\circ} \mathrm{C}, \mathrm{C}$ content of $\mathrm{KOH}$-enhanced biochars generally decreased compared to 0B biochar samples (Tables S1 and S2). This was likely due to a removal of more non-fixed carbon in feedstock biomass by $\mathrm{KOH}$ during pyrolysis (Huang et al. 2017) and a relative increase in the mass of alkali agent as ash components (Agrafioti et al. 2013). In addition, as expected, biochar total $\mathrm{K}$ and $\mathrm{Ca}$ contents were significantly elevated with specific amendment ratio of $\mathrm{KOH}, \mathrm{K}_{2} \mathrm{CO}_{3}$ and $\mathrm{CaO}$, respectively. Overall, similar to non-enhanced biochar, all three alkali pretreatments affected the output yield, ash content, and $\mathrm{pH}$ as well as part of elemental composition of prepared biochars at different pyrolysis temperatures. Also, the significantly enhanced total $\mathrm{K}$ content of $\mathrm{KOH}$ and $\mathrm{K}_{2} \mathrm{CO}_{3}$-enhanced biochars could function as $\mathrm{K}$ source in soil biochar amendment.

Several studies have investigated the influence of alkali agents on biomass $\mathrm{C}$ transformation during pyrolysis (Azargohar and Dalai 2006; Chen et al. 2020; Yang et al. 2020; Zhao et al. 2020). In general, decarboxylation reaction was known as the main process to remove $\mathrm{C}$ from feedstock during pyrolysis and it had similar preference for biomass as dehydration reaction under low temperature pyrolysis (Liu and Han 2015). In addition, decarboxylation reaction was shown to dominate at pyrolysis temperature above $350^{\circ} \mathrm{C}$, whereas decarbonylation reaction was at above $450{ }^{\circ} \mathrm{C}$ (Zhang et al. 2020). At $550{ }^{\circ} \mathrm{C}$, biochar exhibited stable characteristic atomic ratios of $\mathrm{H} / \mathrm{C}<0.4$ and $\mathrm{O} / \mathrm{C}<0.2$ (Jeong et al. 2016) and significant fusion into aromatic ring structure (Zhang et al. 2020). The higher pyrolysis temperature mainly promoted the decomposition of the volatiles into the gaseous products while did not promote the decomposition of biochar significantly (Zhang et al. 2020). In our study, the clear decrease in $\mathrm{C}$ contents of alkali-enhanced biochars at $550{ }^{\circ} \mathrm{C}$ compared to $\mathrm{OB}$ biochars indicated the significant role of alkali pretreatment (Tables S1 and S2). Alkali agent such as $\mathrm{KOH}$ was found to promote dehydration, decarboxylation, and decarbonylation reactions with biomass during pyrolysis (Yang et al. 2020; Zhao et al. 2020). The KOH treatment could enhance the decomposition of volatile intermediate, strengthen the reaction with stable $\mathrm{C}$ fragments, and facilitate the overall reaction rate with $\mathrm{C}$ matrix of biomass (Azargohar and Dalai 2006; Chen et al. 2020).

\subsection{Effect of pyrolysis temperature and alkali treatment on biochar phytolith-Si release}

Biochar total Si content generally increased with increasing pyrolysis temperature. However, total Si content of some treatments such as RS-5KB and RH-5K2B decreased from 450 to $550{ }^{\circ} \mathrm{C}$. The loss was probably due to the formation of trace silica scale sticking to the wall of crucible during the production of alkali-enhanced biochar. Similar trend of lower total Si content was also observed when biochar pyrolysis temperature increased from 300 to $700{ }^{\circ} \mathrm{C}$ (Huang et al. 2020).

Non-enhanced biochar (0B) samples showed the higher 5dSCAN-Si content at $350{ }^{\circ} \mathrm{C}$ pyrolysis temperature, and it had lower extractable $\mathrm{Si}$ as pyrolysis temperature was increased to $550{ }^{\circ} \mathrm{C}$ (Fig. 2). This result was consistent with the research of Xiao et al. (2014), who reported higher Si dissolution release from pristine rice straw biochar of $350{ }^{\circ} \mathrm{C}$ than that of biochars prepared at lower $\left(150-250{ }^{\circ} \mathrm{C}\right)$ and higher $\left(500-700{ }^{\circ} \mathrm{C}\right)$ pyrolysis temperatures. Nguyen et al. (2014) also reported higher $\mathrm{Si}$ dissolution from rice straw ashing at $400{ }^{\circ} \mathrm{C}$ than that at $600-800{ }^{\circ} \mathrm{C}$. Based on various spectroscopic analyses of structure, morphology and species, Xiao et al. (2014) proposed a C-Si-C structure model to explain this phenomenon. According to these authors, polymerization of monosilicic acid dominated at $<250{ }^{\circ} \mathrm{C}$ through dehydration to result in a dense $\mathrm{C}-\mathrm{Si}-\mathrm{C}$ structure in biochar. As pyrolysis temperature was increased to $350{ }^{\circ} \mathrm{C}$, the outermost $\mathrm{C}$ layer began to crack, exposing the inner $\mathrm{Si}$ layer of $\mathrm{C}-\mathrm{Si}-\mathrm{C}$ structural configuration and generating a large amount of dissolved Si. At $500-700{ }^{\circ} \mathrm{C}$, the $\mathrm{C}$ layer of $\mathrm{C}-\mathrm{Si}-\mathrm{C}$ structure was further detached. However, due to crystallization of $\mathrm{Si}$, the cumulative release of dissolved $\mathrm{Si}$ was less than biochar produced at $350{ }^{\circ} \mathrm{C}$ (Xiao et al. 2014; Wang et al. 2018b). The C-Si coupling interaction in response to pyrolysis temperature change was further suggested as the mechanism for mutual protection between $\mathrm{Si}$ and $\mathrm{C}$ from dissolution and responsible for biochar $\mathrm{C}$ stability (Guo and Chen 2014; Wang et al. 2019b). The enhanced $\mathrm{BC}$ stability at pyrolysis temperature at above $500{ }^{\circ} \mathrm{C}$ was attributable to the increased aromaticity along with $\mathrm{Si}$ encapsulation of $\mathrm{C}$ and $\mathrm{Si}$ components changing from amorphous to crystalline and from metastable $\alpha$-quartz to stable $\beta$-quartz phase, which is intertwined with C (Guo and Chen 2014). In our study, through alkali pretreatment, 5dSCAN-Si content of resulting biochars was clearly increased as evidenced in $10 \mathrm{~KB}, 10 \mathrm{~K} 2 \mathrm{~B}$ and 10CB samples as pyrolysis temperature was increased from 350 to $550{ }^{\circ} \mathrm{C}$ (Fig. 2). In a previous study, we explored the release mechanism of phytolith-Si in alkali-enhanced biochar at $550{ }^{\circ} \mathrm{C}$ and showed that alkali such as $\mathrm{KOH}$ pretreatment could significantly damage the dumbbell structures of phytoliths that are stacked in layers by exposing the outermost layers of phytoliths for Si release (Wang et al. 2018a). Liu et al. (2012) also indicated that $\mathrm{KOH}$ could be embedded into the interior of phytolith and react with $\mathrm{SiO}_{2}$ to generate less stable silicate as: 


$$
2 \mathrm{KOH}+\mathrm{SiO}_{2} \rightarrow \mathrm{K}_{2} \mathrm{SiO}_{3}+\mathrm{H}_{2} \mathrm{O}
$$

It is well known that $\mathrm{K}_{2} \mathrm{SiO}_{3}$ dissolution is much greater than $\mathrm{SiO}_{2}$ due to the change in silicate structure from threedimensional tectosilicate to single-chained inosilicate (Sparks 2003). While increased pyrolysis temperature could accelerate the burst of $\mathrm{C}$ layer of $\mathrm{C}-\mathrm{Si}-\mathrm{C}$ structural configuration and expose $\mathrm{Si}$ in the inner layer (Xiao et al. 2014), the enhanced contact of alkali reagents with inner Si layer accelerated the Si dissolution rather than Si crystallization in biochar (Fig. S1). The SEM-EDX image and elemental mapping clearly showed bleaching out of photolith-Si with $\mathrm{KOH}$ treatment while $\mathrm{CaO}$ treatment had less impact due to weak base nature and that $\mathrm{CaO}$ tended to stay on phyolith structural surface (Fig. S1). The latter likely explained the trend reversal in 5dSCAN-extractable Si of 10KB, 10K2B and $10 \mathrm{CB}$ as compared to $0 \mathrm{~B}$ samples over increasing pyrolysis temperature.

The higher 5dSCAN-extractable Si content in alkalienhanced biochars compared to non-enhanced biochars as influenced by pyrolysis temperature was also supported by cumulative release of Si over 30 days in unbuffered weak acid and neutral salt solutions (Figs. 4 and 5). Among rice husk and straw biochars prepared at different pyrolysis temperatures, alkali-enhanced biochars (5K2B and 10K2B) had the highest Si release in unbuffered weak acid and neutral salt solutions, and was also higher than feedstocks (RS and RH) and conventional Si fertilizers (WO and SL). The increase in pyrolysis temperature generally significantly increased Si release of alkali-enhanced 5K2B and 10K2B samples while it had less effect on non-enhanced $0 \mathrm{~B}$ samples. This was consistent with the result of 5dSCAN-extractable $\mathrm{Si}$ content of alkali-enhanced biochars prepared at different temperatures (Fig. 2). These results further indicate the importance of alkali pretreatment, especially $\mathrm{K}_{2} \mathrm{CO}_{3}$, and appropriate higher pyrolysis temperature $\left(550{ }^{\circ} \mathrm{C}\right)$ in preparing biochar Si fertilizer.

\subsection{Effect of pyrolysis temperature on Si uptake from alkali-enhanced biochar}

The unique Si dissolution and release characteristics of biochar with higher Si dissolution at $350-400{ }^{\circ} \mathrm{C}$ than the temperature out of this range noted by Xiao et al. (2014) and Nguyen et al. (2014) suggested that pyrolysis temperature could be an important factor to control Si release of biochars in soil. This phenomenon was, however, never examined previously through plant response, although several studies demonstrated that biochar made from Si-rich waste biomass could be used as a Si fertilizer source (Houben et al. 2014; Liu et al. 2014; Li et al. 2014, 2018; Abbas et al. 2017). Most biochars used as soil amendment for agronomic application were prepared at temperatures greater than $450{ }^{\circ} \mathrm{C}$ to enhance $\mathrm{C}$ stability and to improve soil water and nutrient retention (Laird 2008; Spokas et al. 2012; Jeong et al. 2016). On the other hand, Wang et al. (2018a) showed that alkalienhanced biochar could significantly increase extractable $\mathrm{Si}$ content of phytolith-rich biochars using AAPFCO-designated 5dSCAN extraction method for Si fertilizer evaluation. In this study, the greenhouse potting trial clearly showed that amendments of all biochars increased rice straw Si content. Treatment of the soil with alkali-enhanced rice husk biochar prepared at $550{ }^{\circ} \mathrm{C}$ (RH-10K2B-550) led to the highest $\mathrm{Si}$ uptake, greater than that of wollastonite and slag (Fig. 6). Most importantly, the same biochar treatment also showed the highest grain yield increase among all biochar amendments and had comparable or higher grain yield than the wollastonite and slag treatments (Fig. 7). The higher grain yield was correlated with the greater cumulative Si release in unbuffered weak acid and neutral salt solutions from alkalienhanced biochars at $550{ }^{\circ} \mathrm{C}$ than from those prepared at $350{ }^{\circ} \mathrm{C}$ or from non-enhanced biochars (0B) (Figs. 4 and 5).

In addition, the difficulty in indexing fertilizer Si sources should be pointed out. Although different chemical methods have been used to evaluate fertilizer Si sources, various studies showed no single extraction that could predict $\mathrm{Si}$ availability (Haynes et al. 2013; Zellner et al. 2015). Therefore, the specific response of plant growth is especially important for evaluating different Si sources, particularly when it comes to biochar-based Si fertilizer. A recent study indicated that the chemical methods that could extract more Si quantitatively from both mineral fertilizers and biomassbased thermal products as well as could reproduce soil root conditions by buffering $\mathrm{pH}$ close to neutral likely do better in correlating with plant Si uptake (Duboc et al. 2019). In our study, we used unbuffered weak acid $(0.1 \mathrm{mM} \mathrm{HCl})$ and neutral salt solution $(0.01 \mathrm{M} \mathrm{KCl})$ to assess Si release over 30 days. The 30-day cumulative $\mathrm{Si}$ release in the unbuffered $0.1 \mathrm{mM} \mathrm{HCl}$ and $0.01 \mathrm{M} \mathrm{KCl}$ solutions showed good correlations with rice straw Si uptake $(r=0.879$ and 0.881 , $P<0.05$, respectively). In addition, they were strongly correlated with rice grain yields $(r=0.924$ and $0.890, P<0.01$, respectively) (Figs. S3 and S4). Among the four extraction methods, 1hSCAN and ammonium acetate extractions were found most closely correlated with rice yield $(r=0.708$, $P<0.05)$. Nonetheless it was clear that alkali-enhanced biochar at $550{ }^{\circ} \mathrm{C}$, especially $\mathrm{K}_{2} \mathrm{CO}_{3}$ pretreatment, facilitated better rice $\mathrm{Si}$ uptake and grain yield than the non-enhanced biochars or biochars prepared at lower temperatures.

It should be pointed out while the enhanced phytolith-Si solubility of biochar by alkali pretreatment likely primarily contributed to the greater rice Si uptake and higher yield, the potentially stronger interaction between biochar and rice roots could play a role. Recent work suggested that biochar amendment could cause an increase in electrical potential difference between rice root membrane and soil due to 
increased soil $\mathrm{E}_{\mathrm{h}}$ and $\mathrm{pH}$, which improves nutrient uptake (Quin et al. 2015; Sun et al. 2017; Chew et al. 2020). Biochar particles were found to be embedded into the plaque layer formed on rice roots and root hairs could enter the pores of biochar (Joseph et al. 2013). According to Zeng et al. (2014) and Haruta et al. (2018), $\mathrm{O}_{2}, \mathrm{~K}^{+}$and $\mathrm{pH}$ are some of key environmental factors influencing plant root membrane potentials. Although we did not measure rhizosphere $\mathrm{E}_{\mathrm{h}}$ change in potting study, the generally high $\mathrm{pH}$ and $\mathrm{K}$ content of alkali-enhanced biochars used in the study (Table S1) would be expected to increase root membrane/soil potential difference due to increased soil $\mathrm{E}_{\mathrm{h}}$ with increasing $\mathrm{pH}$, which drives nutrient uptake (Chew et al. 2020; Zeng et al. 2014). Sufficient $\mathrm{K}$ nutrient could ensure $\mathrm{K}^{+}$-signaling that mediates plant-adaptive response to environment including those of Si-specific transporters (Hosseini et al. 2017). Both could help improve $\mathrm{Si}$ uptake as monosilicic acid uptake besides solubilizing phytoliths-Si.

\section{Conclusion}

This study demonstrated the influence of pyrolysis temperature on the Si release of alkali-enhanced biochars. Different from unenhanced biochar, which generally showed higher chemically extractable $\mathrm{Si}$ when prepared at $350{ }^{\circ} \mathrm{C}$, alkalienhanced biochar, especially with $\mathrm{KOH}$ or $\mathrm{K}_{2} \mathrm{CO}_{3}$, tended to have higher extractable $\mathrm{Si}$ when it was prepared at $550{ }^{\circ} \mathrm{C}$. In addition, biochar prepared with $\mathrm{K}_{2} \mathrm{CO}_{3}$ pretreatment at $550{ }^{\circ} \mathrm{C}$ released more $\mathrm{Si}$ to weak acid and unbuffered neutral salt solutions over 30 days. The greenhouse potting trial also showed that rice plants responded, with greater $\mathrm{Si}$ uptake and grain yield, to alkali-enhanced biochar. Overall, $550{ }^{\circ} \mathrm{C}$ was the better pyrolysis temperature to prepare alkali-enhanced biochar that could increase Si release for plant growth as compared to 350 or $450{ }^{\circ} \mathrm{C}$. Additionally, $\mathrm{KOH}$ - or $\mathrm{K}_{2} \mathrm{CO}_{3}$-enahnced biochar can provide $\mathrm{K}$ source besides enhanced $\mathrm{C}$ stability.

Supplementary Information The online version contains supplementary material available at https://doi.org/10.1007/s42773-021-00112-3.

Acknowledgements This work was, in part, supported by the Louisiana Board of Regents Support Fund \#LEQSF(2017-18)-RD-D02 and \#LEQSF(2019-20)-RD-D-01, the USDA National Institute of Food and Agriculture Hatch Project \#1013888, and the Shaanxi University of Technology Talent Startup Program (SLGRC19), Hanzhong, Shaanxi, China.

\section{Declarations}

Conflict of interests The authors have no conflicts of interest to declare that are relevant to the content of this article.
Open Access This article is licensed under a Creative Commons Attribution 4.0 International License, which permits use, sharing, adaptation, distribution and reproduction in any medium or format, as long as you give appropriate credit to the original author(s) and the source, provide a link to the Creative Commons licence, and indicate if changes were made. The images or other third party material in this article are included in the article's Creative Commons licence, unless indicated otherwise in a credit line to the material. If material is not included in the article's Creative Commons licence and your intended use is not permitted by statutory regulation or exceeds the permitted use, you will need to obtain permission directly from the copyright holder. To view a copy of this licence, visit http://creativecommons.org/licenses/by/4.0/.

\section{References}

Abbas T, Rizwan M, Ali S, Zia-ur-Rehman M, Qayyum MF, Abbas F, Hannan F, Rinklebe J, Ok YS (2017) Effect of biochar on cadmium bioavailability and uptake in wheat (Triticum aestivum L.) grown in a soil with aged contamination. Ecotoxicol Environ Saf 140:37-47. https://doi.org/10.1016/j.ecoenv.2017.02.028

Adrees M, Ali S, Rizwan M, Zia-ur-Rehman M, Ibrahim M, Abbas F, Farid M, Qayyum MF (2015) Mechanisms of silicon-mediated alleviation of heavy metal toxicity in plant: a review. Ecotoxicol Environ Saf 119:186-197. https://doi.org/10.1016/j.ecoenv.2015. 05.011

Agrafioti E, Bouras G, Kalderis D, Diamadopoulos E (2013) Biochar production by sewage sludge pyrolysis. J Anal Appl Pyrol 101:72-78. https://doi.org/10.1016/j.jaap.2013.02.010

Ahmad M, Lee SS, Dou X, Mohan D, Sung JK, Yang JE, Ok YS (2012) Effects of pyrolysis temperature on soybean stover- and peanut shell-derived biochar properties and TCE adsorption in water. Bioresour Technol 118(8):536-544. https://doi.org/10. 1016/j.biortech.2012.05.042

Azargohar R, Dalai AK (2006) Biochar as a precursor of activated carbon. Humana Press Inc, pp 762-773. https://doi.org/10.1007/ 978-1-59745-268-7-62

Bao SD (2000) Soil agro-chemistry analysis, 3rd edn. China Agriculture Press, Beijing (in Chinese)

Cantrell KB, Hunt PG, Uchimiya M, Novak JM, Ro KS (2011) Impact of pyrolysis temperature and manure source on physicochemical characteristics of biochar. Bioresour Technol 107:419-428. https://doi.org/10.1016/j.biortech.2011.11.084

Chen W, Gong M, Li K, Xia M, Chen Z, Xiao H, Fang Y, Chen Y, Yang $\mathrm{H}$, Chen $\mathrm{H}$ (2020) Insight into $\mathrm{KOH}$ activation mechanism during biomass pyrolysis: Chemical reactions between O-containing groups and $\mathrm{KOH}$. Appl Energy 278:115730. https://doi. org/10.1016/j.apenergy.2020.115730

Chew J, Zhu L, Nielsen S, Graber E, Mitchell DRG, Horvat J, Mohammed M, Liu M, Zwieten L, Fan X (2020) Biochar-based fertilizer: supercharging root membrane potential and biomass yield of rice. Sci Total Environ 713:136431. https://doi.org/10. 1016/j.scitotenv.2019.136431

Duboc O, Robbe A, Santner J, Folegnani G, Gallais P, Lecanuet C, Zehetner F, Nagl P, Wenzel WW (2019) Silicon availability from chemically diverse fertilizers and secondary raw materials. Environ Sci Technol 53(9):5359-5368

Epstein E (2009) Silicon: its manifold roles in plants. Ann Appl Biol 155:155-160. https://doi.org/10.1111/j.1744-7348.2009. 00343.x

Fraysse F, Pokrovsky OS, Schott J, Meunier JD (2006) Surface properties, solubility and dissolution kinetics of bamboo phytoliths. 
Geochim Cosmochim Acta 70:1939-1951. https://doi.org/10. 1016/j.gca.2005.12.025

Guntzer F, Keller C, Meunier JD (2012) Benefits of plant silicon for crops: a review. Agron Sustain Dev 32:201-213. https://doi.org/ 10.1007/s13593-011-0039-8

Guo J, Chen B (2014) Insights on the molecular mechanism for the recalcitrance of biochars: interactive effects of carbon and silicon components. Environ Sci Technol 48(16):9103-9112. https://doi.org/10.1021/es405647e

Hallmark C, Wilding L, Smeck N (1982) Methods of soil analysis. Part 2. Chemical and microbiological properties. American Society of Agronomy Inc, Madison, pp 263-273

Haruta M, Tan LX, Bushey DB, Swanson SJ, Sussman MR (2018) Environmental and genetic factors regulating localization of the plant plasmamembrane H+-ATPase. Plant Physiol 176:364377. https://doi.org/10.1104/pp.17.01126

Haynes RJ, Belyaeva O, Kingston G (2013) Evaluation of industrial wastes as sources of fertilizer silicon using chemical extractions and plant uptake. J Plant Nutr Soil Sci 176:238-248. https://doi. org/10.1002/jpln.201200372

Hosseini SA, Maillard A, Hajirezaei MR, Ali N, Schwarzenberg A, Jamois F, Yvin J-C (2017) Induction of barley silicon transporter HvLsi1 and HvLsi2, increased silicon concentration in the shoot and regulated Starch and ABA homeostasis under osmotic stress and concomitant potassium deficiency. Front Plant Sci 8:1359. https://doi.org/10.3389/fpls.2017.01359

Houben D, Sonnet P, Cornelis JT (2014) Biochar from Miscanthus: a potential silicon fertilizer. Plant Soil 374:871-882. https://doi. org/10.1007/s11104-013-1885-8

Huang CYL, Schulte E (1985) Digestion of plant tissue for analysis by ICP emission spectroscopy. Soil Sci Plant Anal 16:943-958. https://doi.org/10.1080/00103628509367657

Huang H, Tang J, Gao K, He R, Zhao H, Werner D (2017) Characterization of $\mathrm{KOH}$ modified biochars from different pyrolysis temperatures and enhacned adsorptionn of antibiotics. RCS Adv 7:14640-14648. https://doi.org/10.1039/C6RA27881G

Huang F, Gao L, Wu R, Wang H, Xiao R (2020) Qualitative and quantitative characterization of adsorption mechanisms for Cd2+ by silicon-rich biochar. Sci Total Environ 731:139163. https://doi.org/10.1016/j.scitotenv.2020.139163

Iler KR (1979) The chemistry of silica. John Wiley \& Sons, New York

Islam W, Tayyab M, Khalil F, Hua Z, Huang Z, Chen HYH (2020) Silicon-mediated plant defense against pathogens and insect pests. Pestic Biochem Physiol 168:104641. https://doi.org/10.1016/j. pestbp.2020.104641

Jeong CY, Dodla SK, Wang JJ (2016) Fundamental and molecular composition characteristics of biochars produced from sugarcane and rice crop residues and by-products. Chemosphere 142:4-13. https://doi.org/10.1016/j.chemosphere.2015.05.084

Joseph S, Graber ER, Chia C, Munroe P, Donne S, Thomas T, Nielse S, Marjo C, Rutlidge H, Pan GX, Li L, Taylor P, Rawal A, Hook J (2013) Shifting paradigms: development of high-efficiency biochar fertilizers based on nano-structures and soluble components. Carbon Management 4:323-343. https://doi.org/10.4155/cmt.13. 23

Kato N, Owa N (1997) Dissolution of slag fertilizers in a paddy soil and Si uptake by rice plants. Soil Sci Plant Nutr 43:329-341. https:// doi.org/10.1080/00380768.1997.10414757

Keiluweit M, Nico PS, Johnson MG (2010) Dynamic molecular structure of plant biomass-derived black carbon (biochar). Environ Sci Technol 44:1247-1253. https://doi.org/10.1021/es9031419

Kim J, Cho T, Choi JW (2012) Influence of pyrolysis temperature on physicochemical properties of biochar obtained from the fast pyrolysis of pitch pine (Pinus rigida). Bioresour Technol 118:158 162. https://doi.org/10.1016/j.biortech.2012.04.094
Korndörfer GH, Snyder GH, Ulloa M, Powell G, Datnoff LE (2001) Calibration of soil and plant silicon analysis for rice production. J Plant Nutr 24:1071-1084. https://doi.org/10.1081/PLN-10010 3804

Korndörfer GH, Pereira HS, Nolla A (2004) Analysis of silicon: soil, plant and fertilizer. Uberlandia, Brazil GPSi-ICIAG-UFU

Kuzyakov Y, Subbotina I, Chen H, Bogomolova I, Xu X (2009) Black carbon decomposition and incorporation into soil microbial biomass estimated by $14 \mathrm{C}$ labeling. Soil Biol Biochem 41:210-219. https://doi.org/10.1016/j.soilbio.2008.10.016

Laird DA (2008) The charcoal vision: a win-win-win scenario for simultaneously producing bioenergy, permanently sequestering carbon, while improving soil and water quality. Agron J 100:178181. https://doi.org/10.2134/agronj2007.0161

Li Z, Song Z, Cornelis JT (2014) Impact of rice cultivar and organ on elemental composition of phytoliths and the release of bioavailable silicon. Front Plant Sci 5:529. https://doi.org/10.3389/ fpls.2014.00529

Li Z, Delvaux B, Yans J, Dufour N, Houben D, Cornelis J (2018) Phytolith-rich biochar increases cotton biomass and siliconmineralomass in a highly weathered soil. J Plant Nutr Soil Sci 181:537-546. https://doi.org/10.1002/jpln.201800031

Liang YC, Ma TS, Li FJ, Feng YJ (1994) Silicon availability and response of rice and wheat to silicon in calcareous soils. Commun Soil Sci Plant Anal 25:2285-2297. https://doi.org/10.1080/ 00103629409369189

Linam F, McCoach K, Limmer MA, Seyfferth AL (2021) Contrasting effects of rice husk pyrolysis temperature on silicon dissolution and retention of cadmium (Cd) and dimethylarsinic acid (DMA). Sci Total Environ 765:144428. https://doi.org/10.1016/j.scitotenv. 2020.144428

Liu Z, Han G (2015) Production of solid fuel biochar from waste biomass by low temperature pyrolysis. Fuel 158:159-165. https://doi. org/10.1016/j.fuel.2015.05.032

Liu P, Liu WJ, Jiang H, Chen JJ, Li WW, Yu HQ (2012) Modification of bio-char derived from fast pyrolysis of biomass and its application in removal of tetracycline from aqueous solution. Bioresour Technol 121:235-240. https://doi.org/10.1016/j.biortech.2012. 06.085

Liu X, Li L, Bian R, Chen D, Qu J, Wanjiru KG, Pan G, Zhang X, Zheng J, Zheng J (2014) Effect of biochar amendment on soil-silicon availability and rice uptake. J Plant Nutr Soil Sci 177:91-96. https://doi.org/10.1002/jpln.201200582

Ma JF, Takahashi E (2002) Soil, fertilizer and plant silicon research in Japan. Elsevier Science, Dordrecht, The Netherlands

Meyer JH, Keeping MG (2001) Past, present and future research of the role of silicon for sugarcane in southern Africa. In: Datnoff LE, Snyder GH, Korndörfer GH (eds) Silicon in agriculture. Elsevier, Amsterdam, pp 257-275

Neumann D, Zur NU (2001) Silicon and heavy metal tolerance of higher plants. Phytochemistry 56:685-692. https://doi.org/10. 1016/S0031-9422(00)00472-6

Nguyen BT, Lehmann J, Hockaday WC, Joseph S, Masiello CA (2010) Temperature sensitivity of black carbon decomposition and oxidation. Environ Sci Technol 44(9):3324-3331. https://doi.org/10. 1021/es903016y

Nguyen N, Dulitz S, Guggenerger G (2014) Effects of pretreatment and solution chemistry on solubility of rice straw phytoliths. J Plant Nutr Soil Sci 177(3):349-359. https://doi.org/10.1002/jpln. 201300056

NIAES (1987) Official methods of analysis of fertilizers, vol. 124. Tsukuba: National Institute of Agroenvironmental Sciences, Foundation Nohrin Kohsaikai, pp 36-37

Novak JM, Busscher WJ, Laird DL, Ahmedna M, Watts DW, Niandou MA (2009) Impact of biochar amendment on fertility of a 
southeastern coastal plain soil. Soil Sci 174:105-112. https://doi. org/10.1097/SS.0b013e3181981d9a

Nwajiaku IM, Olanrewaju JS, Sato K, Tokunari T, Kitano S, Masunaga $\mathrm{T}$ (2018) Change in nutrient composition of biochar from rice husk and sugarcane bagasse at varying pyrolytic temperatures. Int J Recycl Org Waste Agricult 7(4):269-276. https://doi.org/10. 1007/s40093-018-0213-y

Paris O, Zollfrank C, Zickler GA (2005) Decomposition and carbonisation of wood biopolymersda microstructural study of softwood pyrolysis. Carbon NY 43:53-66. https://doi.org/10.1016/j.carbon. 2004.08.034

Quin P, Joseph S, Husson O, Donne S, Mitchell D, Munroe P, Phelan D, Cowie A, Van Zwieten L (2015) Lowering N2O emissions from soils using eucalypt biochar: the importance of redox reactions. Sci Rep 5:16773. https://doi.org/10.1038/srep16773

Saito K, Yamamoto A, Sa T, Saigusa M (2005) Rapid, micro-methods to estimate plant silicon content by dilute hydrofluoric acid extraction and spectrometric molybdenum method. Soil Sci Plant Nutr 51:29-36. https://doi.org/10.1111/j.1747-0765.2005.tb00003.x

Sebastian D, Rodrigues H, Kinsey C, Korndörfer G, Pereira H, Buck G, Datnoff LE, Miranda S, Provance-Bowley M (2013) A 5-day method for determination of soluble silicon concentrations in nonliquid fertilizer materials using a sodium carbonate-ammonium nitrate extractant followed by visible spectroscopy with heteropoly blue analysis: single-laboratory validation. J AOAC Int 96:251259. https://doi.org/10.5740/jaoacint.12-243

Singh BP, Cowie AL, Smernik RJ (2012) Biochar carbon stability in a clayey soil as a function of feedstock and pyrolysis temperature. Environ Sci Technol 46(21):11770-11778. https://doi.org/ $10.1021 / \mathrm{es} 302545 \mathrm{~b}$

Snyder GH (2001) Methods for silicon analysis in plants, soils, and fertilizers. In: Datnoff LE, Snyder GH, Korndörfer GH (eds) Silicon in agriculture. Elsevier, Amsterdam, pp 185-196

Sparks DL (2003) Environmental soil chemsitry, 2nd edn. Academic Press, New York

Spokas KA, Novak JM, Venterea RT (2012) Biochar's role as an alternative N-fertilizer: ammonia capture. Plant Soil 350:35-42. https://doi.org/10.1007/s11104-011-0930-8

Suliman W, Harsh JB, Abu-Lail NI, Fortuna A, Dallmeyer I, GarciaPerez M (2016) Influence of feedstock source and pyrolysis temperature on biochar bulk and surface properties. Biomass Bioenergy 84:37-48. https://doi.org/10.1016/j.biombioe.2015.11.010

Sun TR, Levin BDA, Guzman JJL, Enders A, Muller DA, Angenent LT, Lehmann J (2017) Rapid electron transfer by the carbon matrix in natural pyrogenic carbon. Nat Commun 8:14873. https:// doi.org/10.1038/ncomms14873

Takahashi K (1981) Effects of slags on the growth and the silicon uptake by rice plants and the available silicates in paddy soils. Bull Shikoku Agric Exp Stn 38:75-114
Van Zwieten L, Kimber S, Morris S, Chan K, Downie A, Rust J, Joseph S, Cowie A (2010) Effects of biochar from slow pyrolysis of papermill waste on agronomic performance and soil fertility. Plant Soil 327:235-246. https://doi.org/10.1007/s11104-009-0050-x

Wang JJ, Dodla SK, Henderson RE (2004) Soil silicon extractability with seven selected extractants in relation to colorimetric and ICP determination. Soil Sci 169:861-870. https://doi.org/10.1097/01. ss.0000149362.88935.8d

Wang M, Wang JJ, Wang X (2018a) Effect of KOH-enhanced biochar on increasing soil plant-available silicon. Geoderma 321:22-31. https://doi.org/10.1016/j.geoderma.2018.02.001

Wang Y, Xiao X, Chen B (2018b) Biochar impacts on soil silicon dissolution kinetics and their interaction mechanisms. Sci Rep 8:8040. https://doi.org/10.1038/s41598-018-26396-3

Wang M, Wang JJ, Tafti ND, Hollier CA, Myers G, Wang X (2019a) Effect of alkali-enhanced biochar on silicon uptake and suppression of gray leaf spot development in perennial ryegrass. Crop Prot 119:9-16. https://doi.org/10.1016/j.cropro.2019.01.013

Wang Y, Xiao X, Xu Y, Chen B (2019b) Environmental effects of silicon within biochar (sichar) and carbon-silicon coupling mechanisms: a critical review. Environ Sci Technol 53:13570-13582. https://doi.org/10.1021/acs.est.9b03607

Xiao X, Chen B, Zhu L (2014) Transformation, morphology, and dissolution of silicon and carbon in rice straw-derived biochars under different pyrolytic temperatures. Environ Sci Technol 48:34113419. https://doi.org/10.1021/es405676h

Yang H, Chen Z, Chen W, Chen Y, Wang X, Chen H (2020) Role of porous structure and active $\mathrm{O}$-containing groups of activated biochar catalyst during biomass catalytic pyrolysis. Energy 210:118646. https://doi.org/10.1016/j.energy.2020.118646

Zellner W, Friedrich R, Kim S, Sturtz D, Frantz J, Altland J, Krause C (2015) Continuing assessment of the 5-day sodium carbonate ammonium nitrate extraction assay as an indicator test for silicon fertilizers. J AOAC Int 98(4):890-895. https://doi.org/10.5740/ jaocint.14-205

Zeng F, Konnerup D, Shabala L, Zhou M, Colmer TD, Zhang G, Shabala S (2014) Linking oxygen availability with membrane potential maintenance and $\mathrm{K}+$ retention of barley roots: implications for waterlogging stress tolerance. Plant Cell Environ 372:325-2338. https://doi.org/10.1111/pce.12422

Zhang C, Zhang Z, Zhang L, Li Q, Li C, Chen G, Zhang S, Liu Q, $\mathrm{Hu} X(2020)$ Evolution of the functionalities and structures of biochar in pyrolysis of poplar in a wide temperature range. Bioresour Technol 304:123003. https://doi.org/10.1016/j.biortech.2020. 123002

Zhao C, Ma J, Li Z, Xia H, Liua H, Yang Y (2020) Highly enhanced adsorption performance of tetracycline antibiotics on $\mathrm{KOH}$-activated biochar derived from reed plants. RSC Adv 10:5066. https:// doi.org/10.1039/c9ra09208k 